\title{
Shifts in phytoplankton community structure modify bacterial production, abundance and community composition
}

\author{
Maria T. Camarena-Gómez ${ }^{1,2, *}$, Tobias Lipsewers ${ }^{2}$, Jonna Piiparinen ${ }^{2}$, \\ Eeva Eronen-Rasimus ${ }^{2}$, Daniel Perez-Quemaliños ${ }^{3}$, Laura Hoikkala ${ }^{2,4}$, \\ Cristina Sobrino ${ }^{3}$, Kristian Spilling ${ }^{2}$ \\ ${ }^{1}$ Tvärminne Zoological Station, University of Helsinki, J.A. Palménin tie 260, 10900 Hanko, Finland \\ ${ }^{2}$ Finnish Environment Institute, Marine Research Center, PO Box 140, 00251 Helsinki, Finland \\ ${ }^{3}$ Faculty of Sciences, University of Vigo, Campus Lagoas-Marcosende s/n, 36310 Vigo, Spain \\ ${ }^{4}$ Helsinki University Center for Environment, PO Box 65, 00014 University of Helsinki, Finland
}

\begin{abstract}
In recent decades, the phytoplankton community in parts of the Baltic Sea has shifted from diatom dominance to co-occurrence of diatoms and dinoflagellates during the spring bloom. We investigated whether this shift affects bacterial production (BP), abundance and community composition (BCC). Two mesocosm experiments were carried out with water from the SW coast of Finland during the winters of 2012 and 2013. The water was collected before the onset of the spring bloom. Natural seawater was used as a control, and various inocula of diatom and dinoflagellate cultures were used as treatments. After the phytoplankton bloom development, BP (thymidine: BPT; leucine: BPL) was significantly higher in the diatom treatments than in the controls and dinoflagellate treatments (BPT and BPL in 2012 and BPL in 2013). In 2013, the BCC was significantly different between the diatom and dinoflagellate treatments and there was a temporal shift in both experiments. Alphaproteobacteria predominated in all treatments at the beginning of the experiments and shifted to flavobacterial (2012) and betaproteobacterial predominance (2013) during the chlorophyll a peak. Towards the end of the experiment, Actinobacteria and Betaproteobacteria predominated in the diatom treatment in 2012, whereas in 2013 Flavobacteriia (all treatments) predominated together with Gammaproteobacteria and Cytophagia (diatom treatments). The results demonstrated that bacterial physiology and community structure are affected by relatively small changes in the phytoplankton community. Thus, the ongoing changes in the phytoplankton community resulting from co-occurrence of diatoms and dinoflagellates may decrease pelagic remineralization of carbon and reduce organic matter fluxes through the microbial loop.
\end{abstract}

KEY WORDS: Diatom - Dinoflagellate - Bacterial production ' Bacterial community . Biogeochemical cycles $\cdot$ Microbial loop $\cdot$ Baltic Sea

\section{INTRODUCTION}

The spring bloom is the most important phase of the year in terms of primary production (PP) and carbon fixation in temperate waters (Harris 1986). In contrast to most other temperate coastal areas, where diatoms are typically the dominant group during this period,

*Corresponding author: maria.camarena@environment.fi

$\S_{\text {Corrections }}$ were made after publication. For details see www.int-res.com/articles/ame_oa/a087p205.pdf

This corrected version: December 2, 2021 the phytoplankton spring bloom in several parts of the Baltic Sea is dominated by both diatoms and dinoflagellates, but with spatial and temporal differences in their relative contribution to the biomass (Wasmund et al. 1998, Klais et al. 2011, Lips et al. 2014).

Among the dinoflagellates, at least 4 cold-water species may predominate during the spring bloom

(C) The authors 2018. Open Access under Creative Commons by Attribution Licence. Use, distribution and reproduction are unrestricted. Authors and original publication must be credited.

Publisher: Inter-Research · www.int-res.com 
period in the Baltic Sea (Peridiniella catenata, Biecheleria baltica, Gymnodinium corollarium, and Apocalathium malmogiense). Furthermore, longterm datasets have demonstrated an increase in the abundance of these dinoflagellate species during the spring bloom, most conspicuously in the Gulf of Finland (Klais et al. 2011). In a climate change scenario with mild winters (decrease in ice expansion and thickness, earlier stratification, etc.), dinoflagellate abundance may increase at the expense of diatoms (Wasmund et al. 2011, 2013, Klais et al. 2013). The potential consequences of such changes in ecosystem functioning are still poorly understood.

Diatoms and dinoflagellates have different sedimentation patterns (Heiskanen 1998). Diatoms settle more rapidly than dinoflagellates and transport more organic material with higher carbon:nitrogen:phosphorus (C:N:P) ratios to the seafloor (Arrigo et al. 2012, Spilling et al. 2014), whereas dinoflagellates either lyse before reaching the sediment (Heiskanen 1998) or settle as dormant resting cysts not readily available for remineralization (Spilling \& Lindström 2008). Therefore, diatoms are likely more important than dinoflagellates in terms of input of organic matter to the benthic food web (Heiskanen 1998, Höglander et al. 2004).

Phytoplankton also shape the biochemistry (e.g. the inorganic C:N:P ratio) of the seawater by the uptake of inorganic nutrients, carbon fixation, and release of dissolved organic matter (DOM). For example, the quantity and/or quality of the DOM released by phytoplankton cells during their growth may differ, depending on species-specific properties and the physiological status of the algae (Biddanda \& Benner 1997, Meon \& Kirchman 2001, Thornton 2014). Some diatoms release large proportions $(>20 \%)$ of fixed carbon as dissolved organic carbon (DOC), but this is highly species-specific (Wetz \& Wheeler 2007). Some dinoflagellates show higher percentages of extracellular release than diatoms (Castillo et al. 2010, López-Sandoval et al. 2013). However, during the spring bloom in the Baltic Sea, diatom-dominated communities excrete more DOC than mixed or dinoflagellate-dominated communities (Spilling et al. 2014).

In addition to the release of DOM by phytoplankton cells, other processes, such as viral lysis, sloppy feeding, and cell death, may also contribute to the production of the DOM pool. Hence, this pool is highly diverse, consisting of labile and refractory parts, which can also be divided into low- (LMW) and high-molecular-weight (HMW) compounds (Amon \& Benner 1996). For example, Thornton (2014) classi- fied the cellular DOM released, based on its chemical composition, as amino acids, carbohydrates, fatty acids and lipids, nucleic acids, glycolate, dimethylsulfoniopropionate, dimethyl sulfide, and isoprene. Of these, carbohydrates (mono- and polysaccharides) are most commonly released by the algae (Myklestad 1995, Urbani et al. 2005, Thornton 2014) and more specifically by diatoms, as well as amino acids and proteins (Myklestad 2000). Fatty acids and lipids are excreted by both diatoms and dinoflagellates (Parrish et al. 1994). The labile part of DOC is either respired or transformed into biomass and rapidly channeled to higher trophic levels through the microbial loop (Azam et al. 1983, Smith et al. 1995). Another part of the carbon biomass transformed through microbial metabolism is released and contributes to the refractory DOC pool, which can resist bacterial degradation (Jeong et al. 2010).

The proportion of carbon released or leaked as DOC under stressful conditions (e.g. high temperature and nutrient limitation) may increase as a consequence of climate warming (Thornton 2014). This would have a bottom-up effect on ecosystem functioning by increasing the amount of organic carbon going through the microbial loop. However, since DOC release is highly species-specific, further empirical studies are needed at the phytoplankton and bacterioplankton community levels to improve our understanding of the effect of plankton community structure on carbon cycling through the microbial loop.

The close association between primary producers and heterotrophic bacteria, defined as bacteriaphytoplankton coupling, has been observed for decades (Cole et al. 1988, Baines \& Pace 1991, Morán et al. 2002). Phytoplankton cells produce a successive availability of various algal-derived products as DOM, which provides a series of ecological niches for bacteria and leads to changes in bacterial growth rate and community composition (Biddanda \& Benner 1997, Riemann et al. 2000, Buchan et al. 2014). For example, Alphaproteobacteria are typically abundant in the phytoplankton pre-bloom phase, whereas Bacteroidetes and Gammaproteobacteria are abundant during and/or after the bloom (Cottrell \& Kirchman 2000, Pinhassi et al. 2004, Teeling et al. 2012). In addition to these predominant groups, Actinobacteria and Betaproteobacteria are also common members of the bacterial community in the brackish Baltic Sea during or after phytoplankton blooms (Riemann et al. 2008, Herlemann et al. 2011, Bunse et al. 2016). A recent study using metagenome-assembled genomes linked these phylogenetic lineages with 
Table 1. Inorganic nutrient concentrations of nitrite + nitrate nitrogen $\left(\mathrm{NO}_{2}+\mathrm{NO}_{3}-\mathrm{N}\right)$, ammonium nitrogen $\left(\mathrm{NH}_{4}-\mathrm{N}\right)$, phosphate phosphorus $\left(\mathrm{PO}_{4}-\mathrm{P}\right.$ ), and dissolved silica (DSi) in $\mu \mathrm{g} \mathrm{l}^{-1}$ (mean $\pm \mathrm{SE}, \mathrm{n}=3$ ) at the start of the experiment (Day 0) and on the day of the chlorophyll a (chl a) peak in 2012 (Day 10 for DIATOM and DINOF treatments, Day 19 for CONTR1 treatment) and 2013 (Day 15). CONTR: control, DIATOM: diatom addition, DINOF: dinoflagellate addition (see 'Materials and methods' for species details); AT: Achnanthes taeniata, TB: Thalassiosira baltica, BB: Biecheleria baltica additions

\begin{tabular}{|c|c|c|c|c|c|c|c|}
\hline & \multicolumn{3}{|c|}{-2012} & \multirow[b]{2}{*}{ CONTR2 } & \multirow[b]{2}{*}{ AT } & \multirow[b]{2}{*}{ TB } & \multirow[b]{2}{*}{$\mathrm{BB}$} \\
\hline & CONTR1 & DIATOM & DINOF & & & & \\
\hline \multicolumn{8}{|l|}{ Day 0} \\
\hline $\mathrm{NO}_{2}+\mathrm{NO}_{3}-\mathrm{N}$ & $97.47 \pm 1.68$ & $108.57 \pm 1.33$ & $98.53 \pm 0.92$ & $80.20 \pm 3.29$ & $91.80 \pm 4.10$ & $89.03 \pm 2.54$ & $86.40 \pm 1.28$ \\
\hline $\mathrm{NH}_{4}-\mathrm{N}$ & $1.93 \pm 0.26$ & $1.80 \pm 0.38$ & $1.77 \pm 0.07$ & $0.03 \pm 0.00$ & $0.10 \pm 0.00$ & $0.00 \pm 0.00$ & $0.13 \pm 0.00$ \\
\hline $\mathrm{PO}_{4}-\mathrm{P}$ & $31.21 \pm 0.09$ & $32.07 \pm 0.09$ & $30.33 \pm 0.17$ & $27.40 \pm 0.43$ & $27.23 \pm 0.60$ & $27.83 \pm 0.77$ & $27.50 \pm 0.42$ \\
\hline $\mathrm{DSi}$ & $623.83 \pm 0.33$ & $628.0 \pm 4.59$ & $620.70 \pm 3.06$ & $500.20 \pm 0.79$ & $506.23 \pm 1.80$ & $505.70 \pm 4.42$ & $500.03 \pm 2.48$ \\
\hline \multicolumn{8}{|l|}{ Day chl a peak } \\
\hline $\mathrm{NO}_{2}+\mathrm{NO}_{3}-\mathrm{N}$ & $0.97 \pm 0.20$ & $1.10 \pm 0.0$ & $2.15 \pm 2.92$ & $1.70 \pm 0.10$ & $2.17 \pm 0.21$ & $1.97 \pm 0.03$ & $2.03 \pm 0.03$ \\
\hline $\mathrm{NH}_{4}-\mathrm{N}$ & $1.70 \pm 0.32$ & $2.06 \pm 0.32$ & $0.63 \pm 0.16$ & $1.33 \pm 0.27$ & $0.63 \pm 0.34$ & $0.83 \pm 0.49$ & $0.53 \pm 0.39$ \\
\hline $\mathrm{PO}_{4}-\mathrm{P}$ & $0.99 \pm 0.13$ & $2.89 \pm 0.34$ & $1.74 \pm 0.35$ & $2.23 \pm 0.48$ & $1.53 \pm 0.21$ & $1.80 \pm 0.17$ & $2.03 \pm 0.52$ \\
\hline $\mathrm{DSi}$ & $17.7 \pm 1.50$ & $162.87 \pm 37.87$ & $553.90 \pm 10.89$ & $62.67 \pm 23.89$ & $102.20 \pm 5.80$ & $103.27 \pm 21.04$ & $171.93 \pm 10.73$ \\
\hline
\end{tabular}

functionality, based on the proportion of various genes involved in metabolic processes (Hugerth et al. 2015).

Environmental factors such as salinity, seasonality, temperature, and inorganic nutrients can shape the structure of the bacterial community composition (BCC) (Lindh et al. 2015, Herlemann et al. 2016, Kirchman et al. 2017). Among them, temperature and light are important environmental factors during the development of the spring bloom (Andersson et al. 1994) that can also affect bacterial activity and, thus, the bacteria-phytoplankton coupling (Lindh et al. 2013, von Scheibner et al. 2014, Landa et al. 2016). For example, an increase in temperature from the in situ temperature $\left(2.5^{\circ} \mathrm{C}\right)$ to $6-8^{\circ} \mathrm{C}$ boosted bacterial production (BP) and decreased the time lag between PP and secondary production peaks in several experiments (Hoppe et al. 2008, von Scheibner et al. 2014).

The aim of this study was to determine the effect of the phytoplankton community structure (diatoms vs. dinoflagellates) on the $\mathrm{BCC}$, bacterial abundance (BA), and BP in the Baltic Sea. For this purpose, 2 mesocosm experiments were performed in consecu- tive years (winters of 2012 and 2013), using seawater collected from the ice edge on the SW coast of Finland. Small inocula of various cultured diatoms and dinoflagellates were used to shift the natural phytoplankton community in an attempt to simulate the spring bloom conditions.

\section{MATERIALS AND METHODS}

\section{Experimental setup}

Two mesocosm experiments were carried out at Tvärminne Zoological Station, University of Helsinki: one starting in early March 2012 and the other in late February 2013. The water was collected with a 51 Niskin bottle from the ice edge at Storfjärden $\left(59^{\circ} 50^{\prime} \mathrm{N}, 23^{\circ} 15^{\prime} \mathrm{E}\right)$ at a depth of $20 \mathrm{~m}$, to avoid any influence of fresh water from a nearby river. At the time of water collection, the phytoplankton spring bloom had not yet developed, and the water showed high concentrations of inorganic nutrients (Table 1) and low phytoplankton biomass (Table 2). The water

Table 2. Total carbon biomass (phyto-microzooplankton and nanoflagellates, $\mathrm{mg} \mathrm{Cl}^{-1}$, mean $\pm \mathrm{SE}, \mathrm{n}=3$ ) at the start of the experiment (Day 0) and on the day of the chlorophyll a ( $\mathrm{chl} \mathrm{a)} \mathrm{peak} \mathrm{and} \mathrm{diatom:dinoflagellate} \mathrm{index} \mathrm{(Dia:Dino} \mathrm{index)} \mathrm{during} \mathrm{the} \mathrm{phytoplankton}$ bloom phase in 2012 and 2013. On Day 0, the values of the total carbon biomass are from samples collected before (CONTR1 and CONTR2 for 2012 and 2013, respectively) and after addition of the various phytoplankton inocula; see Table 1 for treatment details

\begin{tabular}{|c|c|c|c|c|c|c|c|}
\hline & \multicolumn{3}{|c|}{-2012} & \multirow[b]{2}{*}{ CONTR2 } & \multirow[b]{2}{*}{ AT } & \multirow[b]{2}{*}{ TB } & \multirow[b]{2}{*}{$\mathrm{BB}$} \\
\hline & CONTR1 & DIATOM & DINOF & & & & \\
\hline Day 0 & $2.69 \pm 1.11$ & $23.59 \pm 2.47$ & $72.62 \pm 50.75$ & $1.35 \pm 0.61$ & $2.40 \pm 0.28$ & $3.22 \pm 0.39$ & $4.44 \pm 3.89$ \\
\hline Day chl a peak & $649.23 \pm 123.16$ & $1894.94 \pm 1111.93$ & $698.56 \pm 96.84$ & $370.96 \pm 17.35$ & $430.39 \pm 18.20$ & $361.76 \pm 29.12$ & $562.86 \pm 27.40$ \\
\hline Dia:Dino index & 0.96 & 0.99 & 0.15 & 0.94 & 1.00 & 0.98 & 0.69 \\
\hline
\end{tabular}


was filtered through a $200 \mu \mathrm{m}$ mesh to exclude large particles and mesozooplankton before filling the experimental containers (20 l square, transparent, polycarbonate containers). The containers were covered with black plastic bags to avoid photoinhibition of the sampled organisms until placed in a climatecontrolled room at $4^{\circ} \mathrm{C}$ and a 12:12 h light:dark cycle. The irradiance was $70 \mu \mathrm{mol}$ photons $\mathrm{m}^{-2} \mathrm{~s}^{-1}$ measured at the surface of the containers with a cosine collector connected to a Walz ULM 500 light meter. Filtered $(0.2 \mu \mathrm{m})$ air was gently bubbled through the containers to avoid particle settling and to provide $\mathrm{CO}_{2}$. No inorganic nutrients were added.

The experimental setup comprised 3 different treatments in 2012 and 4 treatments in 2013, achieved by inoculating the seawater collected with various monocultures of diatoms and dinoflagellates. Each treatment consisted of 3 replicates. In 2012, the treatments were: natural community $=$ no addition (CONTR1), diatom addition (DIATOM), and dinoflagellate addition (DINOF). The phytoplankton species added were a community consisting of Thalassiosira baltica and Chaetoceros wighamii in the DIATOM treatment and a mix of Apocalathium malmogiense, Gymnodinium corollarium, and Biecheleria baltica, constituting a dinoflagellate complex, and Peridiniella catenata in the DINOF treatment. The aim of the cultured community addition was to change the phytoplankton community with minimal increase in the initial biomass. The biomass addition, measured as chlorophyll $a$ (chl a), was 0.7 and $0.4 \mu \mathrm{g} \mathrm{l}^{-1}$ in the DIATOM and DINOF treatments, respectively. These additions represented 1.4 and $0.8 \%$ of the chl a maximum in the DIATOM and DINOF treatments, respectively, and $<0.2 \%$ of the total volume at the time of the addition.

In 2013, the containers were inoculated with monocultures: natural community $=$ no addition (CONTR2); Achnanthes taeniata (AT) and T. baltica (TB) as the treatments with DIATOM addition; and $B$. baltica (BB) as the treatment with DINOF addition. The inoculum was $0.2-0.3 \mu \mathrm{g} \mathrm{l}^{-1} \mathrm{chl} a$ in the $\mathrm{AT}, \mathrm{TB}$, and BB treatments and represented $0.06 \%$ of the chl $a$ maximum and $<0.05 \%$ of the total volume at the time of the addition. All species added are common spring bloom species in the Baltic Sea, and originated from a nonaxenic culture collection or started by isolation of single cells. The cultures were provided by the Marine Research Center, Finnish Environment Institute (SYKE), Finland.

The containers were mixed by stirring prior to each sampling, and subsamples were collected by gentle suction into pre-cleaned bottles. Sampling was carried out 1 to 3 times $\mathrm{wk}^{-1}$, depending on the measurement and the growth phase in the experimental containers. After the inorganic nutrients were depleted in the containers, the temperature was increased to $10^{\circ} \mathrm{C}$. At this point (Day 19 in 2012, Day 22 in 2013), part of the biomass ( $20-30 \%$ of the particulate organic carbon [POC]) was removed by allowing particulate material to settle for $1 \mathrm{~h}$, and $1 \mathrm{l}$ of the settled material was collected by gentle suction through a glass tube. In 2012 , an additional removal ( $55 \%$ of the POC) was done on Day 27. The rationale behind the temperature increase and removal of settled material was to simulate the spring natural environmental conditions with warming of the surface water and settling of POC following the phytoplankton spring bloom. The experiment lasted in total for $41 \mathrm{~d}$ in 2012 and $32 \mathrm{~d}$ in 2013.

\section{Inorganic, particulate, and dissolved organic nutrients and chl $a$}

The inorganic nutrients nitrite + nitrate nitrogen $\left(\mathrm{NO}_{2}+\mathrm{NO}_{3}-\mathrm{N}\right)$, ammonium nitrogen $\left(\mathrm{NH}_{4}-\mathrm{N}\right)$, phosphate phosphorus $\left(\mathrm{PO}_{4}-\mathrm{P}\right)$, and dissolved silica (DSi) were measured according to standard colorimetric methods (Grasshoff et al. 1983). To determine the concentration of POC, particulate organic nitrogen $(\mathrm{PON})$, and particulate organic phosphorus (POP), samples $(100 \mathrm{ml})$ were filtered onto acid-washed, pre-combusted $\left(450^{\circ} \mathrm{C}, 4 \mathrm{~h}\right) \mathrm{GF} / \mathrm{F}$ filters. The dried POC/PON filters were stored at room temperature until measurement with an ANCA-MS 20-20 mass spectrometer (Europa Scientific). The POP was determined according to Solorzano \& Sharp (1980). Samples for biogenic silicate (BSi) were filtered onto $0.8 \mu \mathrm{m}$ polycarbonate filters and measured using the method of Krausse et al. (1983). The DOC and dissolved organic nitrogen (DON) concentrations were measured from $0.2 \mu \mathrm{m}$ filtered samples by the hightemperature catalytic oxidation method, using a Shimadzu TOC-V CPH carbon and nitrogen analyzer (Benner et al. 1993). The DON was measured only in 2013. To determine chl a concentrations, subsamples (25-100 ml) were filtered onto GF/F filters and the chl a was extracted in $10 \mathrm{ml}$ of $96 \%$ ethanol (Jespersen \& Christoffersen 1987). The samples were stored in darkness at $-20^{\circ} \mathrm{C}$ and placed at room temperature for $24 \mathrm{~h}$ before measurement with a Varian Eclipse fluorescent spectrophotometer calibrated against chl a standards (Sigma-Aldrich). All filtrations were done in duplicate. 


\section{Phytoplankton and microzooplankton community composition and biomass}

Samples $(100 \mathrm{ml})$ for the analysis of nano- and microplankton composition were fixed with acid Lugol's solution. At least 400 cells were counted according to Utermöhl (1958), using a Leitz Diavert inverted light microscope. The biovolume and carbon biomass were estimated from microscopy counts, according to Olenina et al. (2006) and Menden-Deuer \& Lessard (2000) for phytoplankton, and Olenina et al. (2006), auf dem Venne (1994), and Putt \& Stoecker (1989) for ciliates. The cysts of dinoflagellate origin were counted from the settled material that was removed and were identified according to Kremp \& Anderson (2000) and Kremp et al. (2005). A modified diatom:dinoflagellate (Dia:Dino) index (using carbon biomass rather than biovolume) was calculated for the phytoplankton bloom phase according to Wasmund et al. (2017). This Dia:Dino index indicates the ratio of diatom to dinoflagellate biomass.

\section{Primary production}

PP was determined by measuring the incorporation of ${ }^{14} \mathrm{C}$-labeled sodium bicarbonate (Nielsen 1952, Gargas 1975). Three $4 \mathrm{ml}$ samples were placed in glass vials and incubated with additions of $10 \mu \mathrm{l}$ of $\mathrm{Na}^{14} \mathrm{CO}_{3}(0.2 \mu \mathrm{Ci}$ final activity) for $2 \mathrm{~h}$ in the climate room $\left(4\right.$ or $\left.10^{\circ} \mathrm{C}\right)$. Two samples per treatment were exposed to $70 \mu \mathrm{mol}$ photons $\mathrm{m}^{-2} \mathrm{~s}^{-1}$, and one was kept in darkness. After the incubation, $100 \mu \mathrm{l}$ of $1 \mathrm{M}$ $\mathrm{HCl}$ were added to the samples and left under a fume hood overnight. The following day ( $24 \mathrm{~h}), 7 \mathrm{ml}$ of liquid scintillation cocktail were added, and the activity was measured in a liquid Wallac Winspectral 1414 scintillation counter. The amount of total dissolved inorganic carbon (DIC) was measured with a Unicarbo high-temperature combustion infrared gas analyzer (Electro-Dynamo Oy). The dark incorporation of ${ }^{14} \mathrm{C}$ was subtracted from the values obtained from the light incubations, and the PP was calculated from the uptake of $\mathrm{Na}^{14} \mathrm{CO}_{3}$, knowing the concentrations of the isotope and DIC added. Due to the relatively short incubation period, the PP measured was assumed to represent gross PP (Sakshaug et al. 1997).

\section{Bacterial production}

BP was measured by determining the simultaneous incorporation of ${ }^{3} \mathrm{H}$-thymidine (TdR) for DNA synthesis (BPT) and ${ }^{14} \mathrm{C}$-leucine (Leu) for protein syntheis (BPL). Three subsamples of 10 or $1 \mathrm{ml}$ (in 2012 and 2013, respectively) were taken from each container. One of the subsamples was fixed with formaldehyde (final concentration $1.85 \%$ ) and served as a blank of non-biological adsorption of the radioisotopes. All samples were spiked with [methyl- $\left.{ }^{3} \mathrm{H}\right]-$ thymidine and $\left[{ }^{14} \mathrm{C}(\mathrm{U})\right]$-leucine (PerkinElmer) at final concentrations of $14-20$ and $100-166 \mathrm{nM}$, respectively. The concentrations were saturating in this region in winter-early spring. The samples were incubated at the experimental temperature $\left(4\right.$ or $\left.10^{\circ} \mathrm{C}\right)$ for $2 \mathrm{~h}$ in darkness. The incubations were stopped by adding formaldehyde to a final concentration of $1.85 \%$. The unincorporated radioactive substrates were removed, using the standard cold trichloroacetic acid (TCA) extraction method (Fuhrman \& Azam 1982). In 2012, the samples (10 ml) were filtered onto $0.2 \mu \mathrm{m}$ mixed cellulose ester filters (Advantec), whereas in 2013 the samples $(1 \mathrm{ml})$ were centrifuged (Smith \& Azam 1992). The filters/pellets were dissolved in Insta-Gel Plus scintillation cocktail (PerkinElmer), and the radioactivity was determined with a Wallac WinSpectral 1414 counter. The TdR incorporation was converted to carbon production

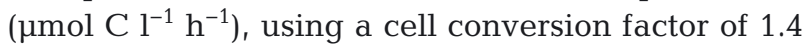
$\times 10^{9}$ cells $\mathrm{nmol}^{-1}$ (HELCOM 2008) and a carbon conversion factor of $0.12 \mathrm{pg} \mathrm{C} \times\left(0.06 \mathrm{\mu m}^{3} \mathrm{cell}^{-1}\right)^{0.7}$ (Norland 1993). The ${ }^{14} \mathrm{C}$-Leu incorporation was converted to carbon production, using the Leu:protein ratio of 0.073 and carbon:protein ratio of 0.86 (Simon \& Azam 1989).

\section{Bacterial abundance}

BA was determined by flow cytometry according to Gasol \& del Giorgio (2000). Sample volumes of $1.2-1.5 \mathrm{ml}$ were fixed with paraformaldehyde (final concentration $1 \%$ ) for $10-15 \mathrm{~min}$ in darkness and stored at $-80^{\circ} \mathrm{C}$ until further processing. Flow cytometry counts were done, staining the cells with SYBR Green I (Sigma-Aldrich). In 2012, an LSRII flow cytometer (BD Biosciences) was used. A known amount of Count bright counting beads (Thermo Fisher Scientific) was added to the sample ( 10\% of the bacterial counts) to estimate the volume measured. The sample was run for $90 \mathrm{~s}$ to obtain $\sim 20000$ events, and the gating of bacterial populations was done using FACS Diva software (BD Biosciences). In 2013, the counts were achieved with a Partec-CUBE flow cytometer equipped with an autosampler, using a counting volume of $25 \mu \mathrm{l}$ and a flow rate of 
$0.5 \mu \mathrm{l} \mathrm{s}^{-1}$. Prior to counting, the samples were diluted 1:10 in $1 \times$ Tris-ethylenediaminetetraacetic acid (TE) buffer, pH 8 (AppliChem). Five runs of each sample were counted to cover the potential internal variation of the flow cytometer. For this set of samples, various suspensions of beads with standard concentrations (Partec) were counted daily before and after the counts for quality control. Gating of bacterial populations was done using the Flow Cytometry Standard Express 4 Flow Research Edition software (DeNovo Software).

\section{Bacterial community composition}

The BCC samples were collected on Day 0 (start), Day 19 (chl a peak), and Day 41 (end) of the experiment in 2012 and on Day 0 (start), Day 13 (chl a peak), and Day 27 (BP peak) of the experiment in 2013. In 2012, the aliquots taken from the 3 replicate containers were pooled by treatment, whereas in 2013 the bacterial community in each container was analyzed separately. Water samples $(500 \mathrm{ml})$ were filtered onto $0.2 \mu \mathrm{m}$ pore-size Whatman cellulose ester filters, which were then stored at $-80^{\circ} \mathrm{C}$ for further processing. DNA extraction was carried out using a Power Soil DNA isolation kit (Mo Bio Laboratories). The 16S ribosomal RNA (rRNA) gene region from V1 to V3 was amplified with a polymerase chain reaction (PCR), using the universal bacterial primers F8 (Chung et al. 2004) and R492 (Edwards et al. 1989). A 2-step PCR and Illumina MiSeq paired-end multiplex sequencing were performed at the Institute of Biotechnology, University of Helsinki, Finland.

Approximately 13 million raw reads of the $16 \mathrm{~S}$ rRNA gene were obtained. Primer removal was done with Cutadapt (Martin 2011). The paired-end reads were merged with a paired-end read merger (Zhang et al. 2014). Quality filtering ( $>400 \mathrm{bp}$, maximum expected error 1), chimera checking (Edgar et al. 2011), and operational taxonomic unit (OTU) clustering (Edgar 2013) were done according to the UPARSE pipeline (Edgar 2013). In total, 1.8 million sequences passed the quality filtering. Taxonomic classification of the OTUs was done with Silva (Quast et al. 2013) in Mothur (Schloss et al. 2009). Chloroplasts, mitochondria, and singletons were removed with Silva, based on the phylogenetic classification, and the libraries were normalized with metagenomeSeq (Paulson et al. 2013), using R (R Development Core Team 2011). In total, 1720 OTUs including 1 million sequences were obtained for further analyses.

\section{Statistics}

Differences between the treatments were tested for BPT, BPL, BA, and DOC in both years. In 2013, tests were also run for DON and BCC. The BPT, BPL, BA, DOC, and DON were analyzed by 1-way analysis of variance (ANOVA), using regression coefficients $(n=3)$ obtained from linear regression analysis run on cumulative sums of each container as the dependent variable and treatment as the factor. The regression analysis and the subsequent ANOVA were run separately for the phytoplankton bloom phase $\left(4^{\circ} \mathrm{C}\right)$ and bacterial bloom phase $\left(10^{\circ} \mathrm{C}\right)$ in each year. The homogeneity of variances was tested with Levene's test, and in case of unequal variances, the data were transformed or ranked. For post hoc testing, Tukey's $b$-test was used. All statistical analyses were done using IBM SPSS 23 software.

A nonmetric multidimensional scaling (NMDS) plot was constructed to visualize the bacterial community dynamics. To determine whether the BCC differed significantly between treatments in 2013 (2012 omitted due to pooling of replicates), repeated measures permutational ANOVA (PERMANOVA) (fixed-factor treatment; AT: $\mathrm{n}=9$, TB: $\mathrm{n}=9$, BB: $\mathrm{n}=9$, CONTR2: $\mathrm{n}=9$ and time: Day 0, chl a peak, and BP peak) with pairwise comparisons (Anderson 2001, McArdle \& Anderson 2001) was done. A total of 9999 permutations, using unrestricted permutation of raw data (Manly 2006), were performed, which is recommended when sample sizes are small (Anderson et al. 2008). The homogeneity of dispersion (i.e. homogeneity of variance) was tested with permutational multivariate analysis of dispersion (Anderson 2006), using the distance to the centroids. All multivariate analyses and NMDS plots were performed on the Bray-Curtis dissimilarity matrix derived from squareroot-transformed normalized values. For the multivariate analyses, PRIMER v. 6 software (Clarke \& Gorley 2006) with the add-on package permutational ANOVA/multivariate ANOVA+ (MANOVA+) (PERMANOVA+) (Anderson et al. 2008) was used.

\section{RESULTS}

The experiments were separated into 2 phases, based on the inorganic nutrient depletion and temperature setup: (1) the phytoplankton bloom phase at $4^{\circ} \mathrm{C}$ with rapid increase in autotrophic biomass (from Day 0 to Day 19) and (2) the bacterial bloom phase at $10^{\circ} \mathrm{C}$ with rapid increase in BP (from Day 19 to Day 41 in 2012 and to Day 32 in 2013). 


\section{Inorganic nutrients and chl a development}

The concentrations of the inorganic nutrients $\left(\mathrm{NO}_{2}\right.$ $+\mathrm{NO}_{3}-\mathrm{N}, \mathrm{NH}_{4}-\mathrm{N}, \mathrm{PO}_{4}-\mathrm{P}$, and $\mathrm{DSi}$ ) were high at the beginning of the experiment in both years (Table 1). There was a drawdown of these nutrients concomitant with the increase in phytoplankton growth. At the chl a peak, $\mathrm{NO}_{2}+\mathrm{NO}_{3}-\mathrm{N}$ and $\mathrm{PO}_{4}-\mathrm{P}$ were almost depleted (Table 1). The $\mathrm{NH}_{4}-\mathrm{N}$ concentration was low or below the detection limit in both years and
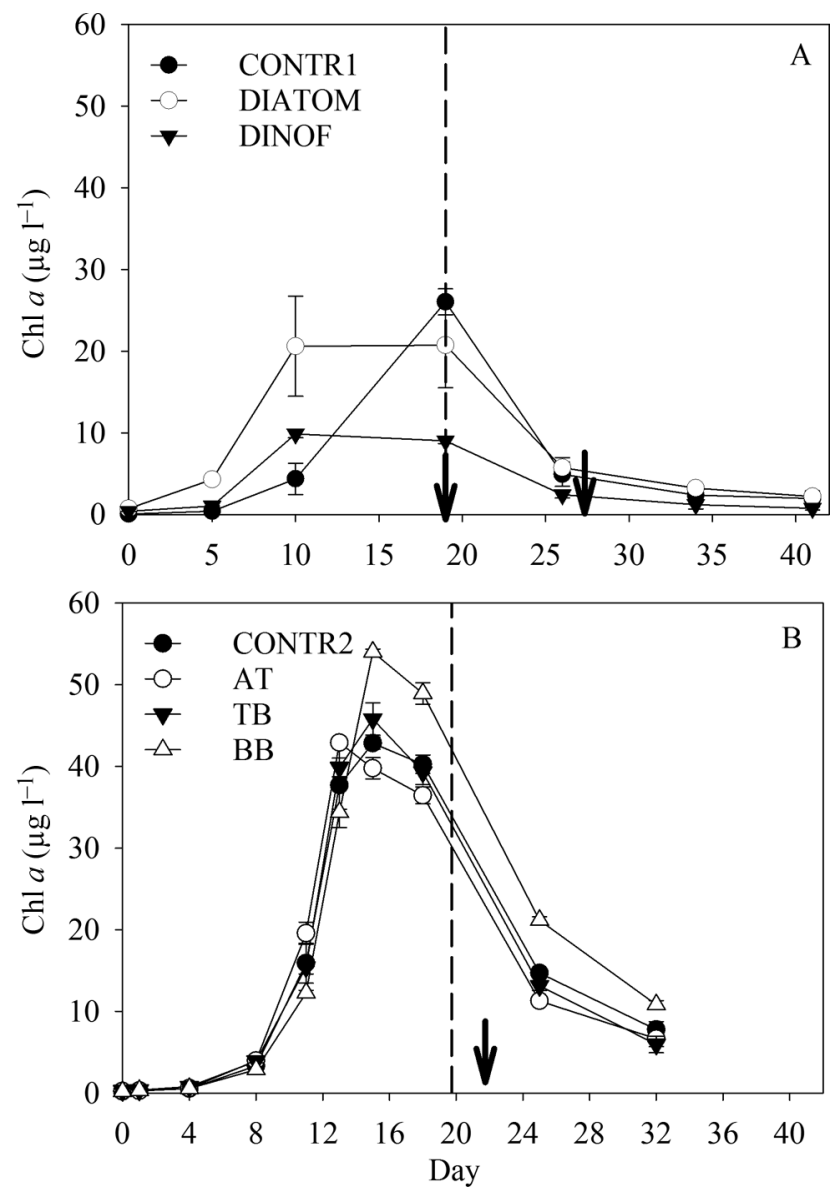

Phytoplankton bloom phase Bacterial bloom phase

Fig. 1. Chlorophyll a concentration (mean $\pm \mathrm{SE}, \mathrm{n}=3$ ) during the experiments in (A) 2012 and (B) 2013. CONTR1 and CONTR2 (controls for 2012 and 2013, respectively) consisted of no addition to the natural plankton community; DIATOM and DINOF treatments consisted of initial addition of diatom and dinoflagellate communities (see 'Materials and methods' for species details); and the AT, TB, and BB treatments consisted of initial additions of Achnanthes taeniata, Thalassiosira baltica, and Biecheleria baltica, respectively. Dashed lines indicate the shift in temperature from 4 to $10^{\circ} \mathrm{C}$ and the separation between the phytoplankton bloom phase (from Day 0 to Day 19) and the bacterial bloom phase (from Day 19 to the end). Arrows depict the sediment removal on Days 19 and 27 in 2012 and on Day 22 in 2013 increased slightly after the chl a peak in 2013. The DSi concentration decreased, particularly in the treatments with diatom addition, but was never completely depleted. In 2012, chl a peaked on Day 10 in 1 replicate of the DIATOM treatment and in all replicates of the DINOF treatment. In the remaining replicates of the DIATOM and CONTR1 treatments, chl a peaked on Day 19 (Fig. 1A). The difference among the DIATOM replicates resulted in larger standard errors (SEs) on Days 10 and 19. Hence, the days selected to define the parameters $\mathrm{NO}_{2}+\mathrm{NO}_{3}-\mathrm{N}, \mathrm{NH}_{4}-$ $\mathrm{N}, \mathrm{PO}_{4}-\mathrm{P}, \mathrm{DSi}$, total carbon biomass, and Dia:Dino index on the day of the chl a peak were set on Day 10 in the DIATOM and DINOF treatments and on Day 19 in the CONTR1 treatment. The maximum $( \pm \mathrm{SE})$ concentrations of chl $a$ in the DIATOM and CONTR1 treatments were similar $(20.60 \pm 6.12$ and $26.03 \pm$ $1.59 \mu \mathrm{g} \mathrm{l}^{-1}$, respectively), whereas in the DINOF treatment, the chl a peak was markedly lower (9.48 \pm $0.48 \mu \mathrm{g} \mathrm{l}^{-1}$ ). In 2013, the chl a peaks were considerably higher than in 2012 (Fig. 1B). The highest chl a value was observed in the BB treatment $(54 \pm 0.40 \mu \mathrm{g}$ $\mathrm{l}^{-1}$ ), whereas in the remaining treatments (CONTR2, $\mathrm{AT}, \mathrm{TB})$ the peaks were similarly lower $(43 \pm 0.80 \mu \mathrm{g}$ $1^{-1}$ ). The chl a peak was reached on Day 13 in the AT treatment and on Day 15 in the other treatments. In 2013, Day 15 was selected to define the values of inorganic nutrient concentrations, total carbon biomass, and Dia:Dino index at the chl a peak.

\section{Dissolved organic carbon and nitrogen}

The DOC concentration was initially high $(\sim 6 \mathrm{mg}$ $\mathrm{C}^{-1}$ ) and increased to $\sim 8 \mathrm{mg} \mathrm{C} \mathrm{l}^{-1}$ during the experiment in both years (Fig. 2A,B), but no significant differences were found between the treatments in the phytoplankton bloom phase or the bacterial bloom phase in either of the years (ANOVA, p $<0.05$; see Table S1 in the Supplement at www.int-res.com/ articles/suppl/a081p149_supp.pdf). Nevertheless, the DIATOM treatment showed the biggest increase in the experiment from 2012, with values almost significantly higher (ANOVA, p = 0.055) compared with the other 2 treatments.

The DON concentration, measured only in 2013, decreased from Day 0 (333 $\left.\mu \mathrm{g} \mathrm{l}^{-1}\right)$ until Day 13, after which it remained stable at $\sim 250 \mu \mathrm{g} \mathrm{l}^{-1}$ in all treatments (Fig. 2C). However, the decrease in DON in the BB treatment was delayed between Days 8 and 13, which was significantly higher than in the CONTR2 and AT treatments during the phytoplankton bloom phase (Tukey's $b, \mathrm{p}<0.05)$. In the bacterial 

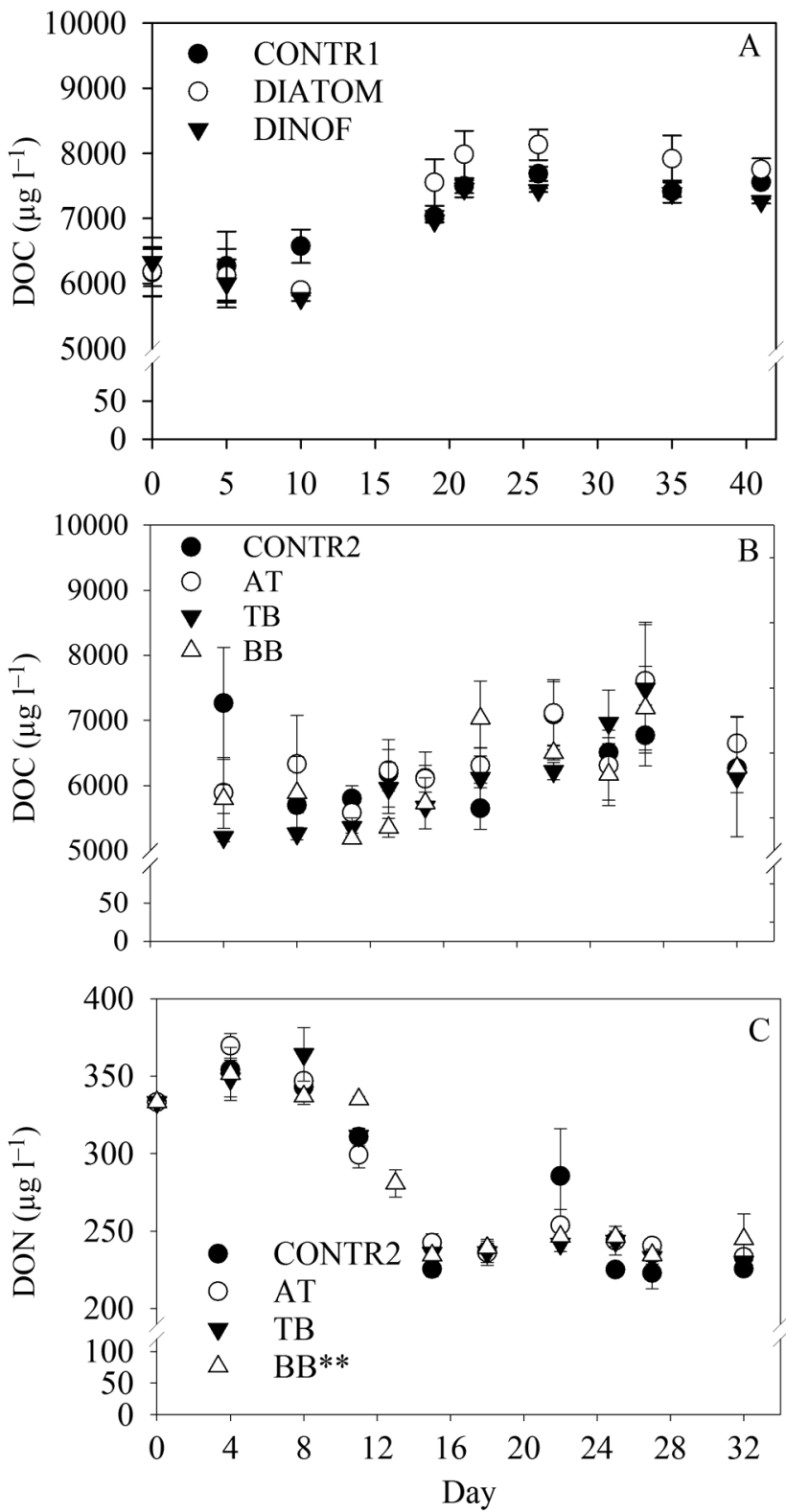

Fig. 2. Dissolved organic carbon (DOC) and dissolved organic nitrogen (DON) concentrations (mean $\pm \mathrm{SE}, \mathrm{n}=3$ ) during the experiments in (A) 2012 and (B,C) 2013. Symbols $\left({ }^{* *}\right)$ indicate the treatment with higher significant differences (ANOVA: $p<0.05$ ) compared to the the controls (CONTR1 and CONTR2 for 2012 and 2013, respectively) in both the phytoplankton and bacterial bloom phase. No symbol indicates no significant differences. DIATOM: diatom addition, DINOF: dinoflagellate addition (see 'Materials and methods' for species details); AT: Achnanthes taeniata, TB: Thalassiosira baltica, BB: Biecheleria baltica additions

bloom phase, the DON concentration was also the highest value shown in the BB treatment, but was significantly different only when compared with the CONTR2 treatment (Tukey's $b, \mathrm{p}<0.05$ ).

\section{Plankton community composition and biomass}

The initial plankton community collected was dominated by ciliates in both years $(43 \%$ in 2012 and $81 \%$ in 2013 ; Fig. 3), which had the highest carbon biomass of the plankton groups, followed by the flagellates in 2012 and the diatoms in both years. At the chl a peak, ciliates accounted for $<7 \%$ of the carbon biomass in both experiments. The ciliates observed were Lohmanniella oviformis, Strombidium sp., Strobilidium sp., and tintinnids (data not shown). Unidentified flagellates constituted $\sim 17 \%$ of the total biomass in the water collected in 2012, whereas in 2013 their contribution was $\sim 1 \%$. At the chl a peak, $7 \%$ of the carbon biomass was flagellates in both years. The species richness in the diatom group was higher in 2012 (6 taxa) than in 2013 (3 taxa), constituting 11.56 and $6.67 \%$ of the total carbon biomass, respectively (Fig. 3A,B). Furthermore, the initial plankton carbon biomass was higher in $2012(2.69 \pm 1.11 \mu \mathrm{g} \mathrm{C}$ $\left.\mathrm{l}^{-1}, \pm \mathrm{SE}\right)$ than in $2013\left(1.35 \pm 0.61 \mathrm{\mu g} \mathrm{C} \mathrm{l}^{-1}\right.$, Table 2$)$. Dinoflagellate cysts were counted as the percentage of the total carbon biomass of cells encysted. The results demonstrated that cyst formation was independent of dinoflagellate abundance and was highly variable among replicates within each treatment (data not shown).

The addition of the inoculum cultures shifted the phytoplankton community in both years, most conspicuously in 2012 when the inoculated biomass was higher than in 2013 (Table 2). In 2012, some of the species added became dominant in their respective treatments: Chaetoceros wighamii, $92 \%$ of the carbon biomass in the DIATOM treatment and the dinoflagellate complex, and $79 \%$ of the carbon biomass in the DINOF treatment, respectively. These species predominated in the DIATOM and DINOF treatments (Dia:Dino index $=0.99$ and 0.15 , respectively) on the day of the chl a peak (Fig. 3A, Table 2). The maximum carbon biomass in the DIATOM treatment was 3.5-fold higher than in the CONTR1 and 3-fold higher than in the DINOF treatment on that day. In 2013, diatoms were the dominant phytoplankton group, with a Dia:Dino index $>0.68$. The naturally occurring diatom Thalassiosira levanderi (not added) became the dominant species in all treatments at the chl a peak (Fig. 3B, Table 2). The contribution of $T$. levanderi was $\sim 43 \%$ of the carbon biomass, followed by Skeletonema marinoi $(\sim 17 \%)$ in the CONTR2 and in the treatments with diatom addition (AT and TB). Achnanthes taeniata formed $10 \%$ and T. baltica $13 \%$ of the biomass in their respective treatments (AT and TB). The dinoflagellate added, Biecheleria baltica, 

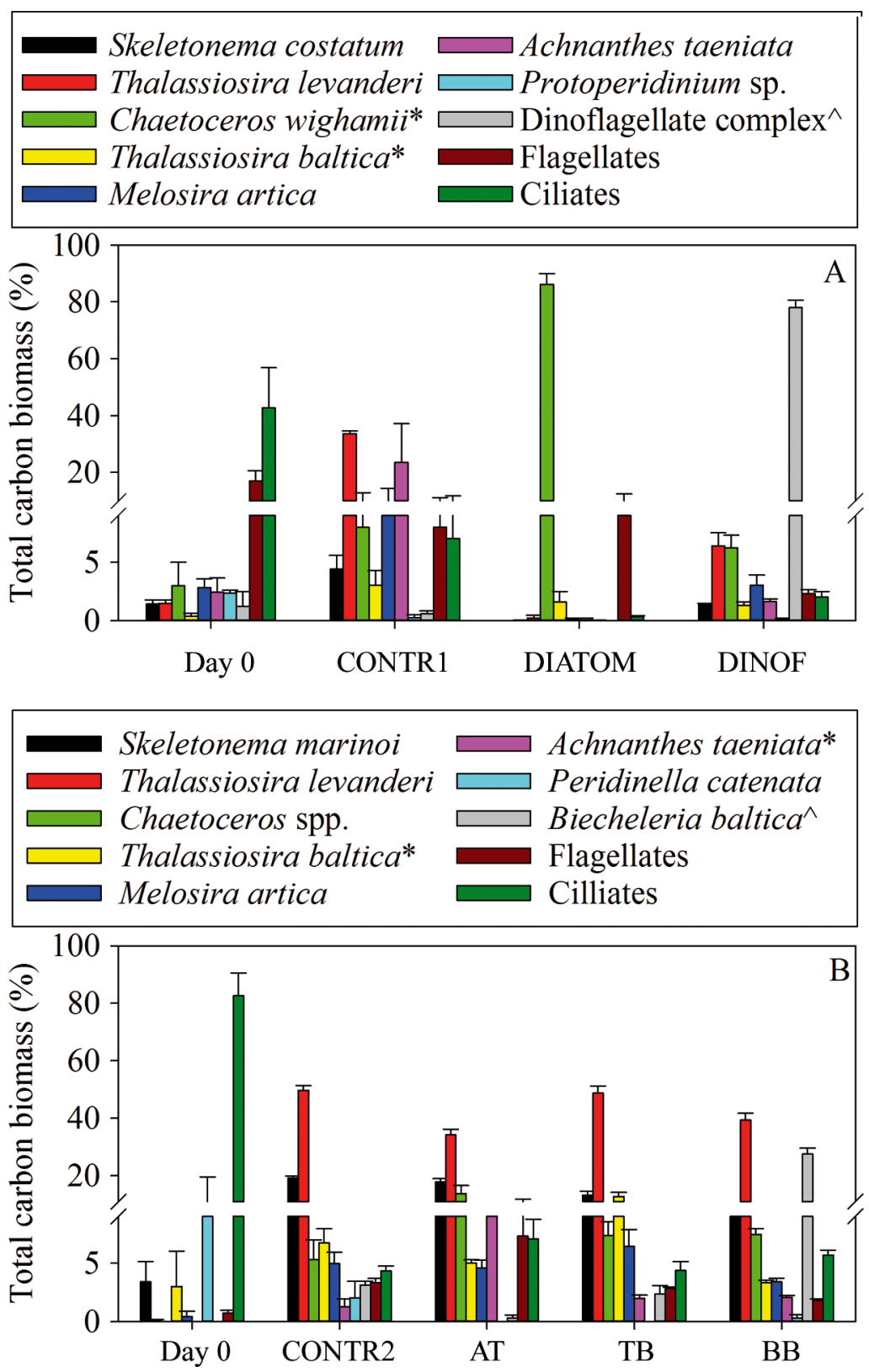

Fig. 3. Composition of the phytoplankton and microzooplankton measured as carbon biomass (mean $\pm \mathrm{SE}, \mathrm{n}=3$ ) in (A) 2012 and (B) 2013 on Day 0 (water collected with algal addition) and on the day of the chlorophyll a peak (see Table 1). The phytoplankton community contributed more than $1 \%$ of the total community. Symbols indicate the species added in each treatment for diatoms $\left({ }^{*}\right)$ and dinoflagellates $\left({ }^{\wedge}\right)$ : DIATOM (Chaetoceros wighamii ${ }^{*}$ and Thalassiosira baltica*), DINOF (dinoflagellate complex ${ }^{\wedge}$ and Peridiniella catenata^), AT (Achnanthes taeniata*), TB (Thalassiosira baltica* ${ }^{*}$, and BB (Biecheleria baltica ${ }^{\wedge}$ ). The dinoflagellate complex is formed by Apocalathium malmogiense, Gymnodinium corollarium, and Biecheleria baltica. CONTR1 (CONTR2): controls for 2012 (2013)

showed the second highest biomass contribution $(28 \%)$ in the corresponding treatment $(\mathrm{BB})$. The carbon biomass was highest in the BB treatment (562.86 $\pm 27.40 \mu \mathrm{g} \mathrm{C} \mathrm{C}^{-1}$ ), whereas in the remaining treatments, the biomass was $\sim 24-36 \%$ lower than in this treatment (Table 2). The controls (CONTR1 and CONTR2) were diatom-dominated during the phytoplankton bloom phase in both years (Dia:Dino index 0.96 and 0.94 in 2012 and 2013, respectively, Table 2).

\section{Primary production}

In general, PP followed the chl a development (Fig. 4). In 2012, the highest PP was observed on Day 10 in the

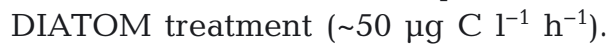
In the DINOF and CONTR1 treatments, the PP peak was lower (Day 10: $22 \mu \mathrm{g}$

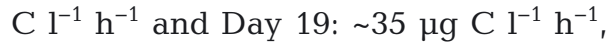
respectively) than in the DIATOM treatment (Fig. 4A). In 2013, 2 PP maxima were observed in all of the treatments (Fig. 4B). The first peak was on Day 13, with the highest value in the

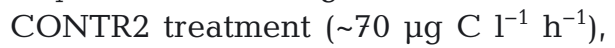
and the second peak was on Day 20 after the temperature increase, with the highest value in the $\mathrm{BB}$ treatment ( 50 $\left.\mu \mathrm{g} \mathrm{C}^{-1} \mathrm{~h}^{-1}\right)$. The second PP peak in the BB treatment was similar to the first peak, whereas in the other treatments the first peak was 1.4-3 times higher than the second peak.

\section{Bacterial production}

The BP, measured as both cell production (TdR-BPT) and protein production (Leu-BPL), followed similar patterns in both years: they increased towards the end of the experiment. During the phytoplankton bloom

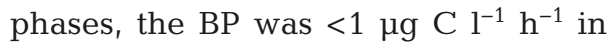
both years, whereas during the bacterial bloom phases, the $\mathrm{BP}$ reached maximum values of BPT $\left(\sim 3 \mu \mathrm{C} \mathrm{Cl}^{-1} \mathrm{~h}^{-1}\right)$ and BPL $\left(5 \mu \mathrm{g} \mathrm{C}^{-1} \mathrm{~h}^{-1}\right)$ in the DIATOM treatment (2012) and BPT ( 1-5 $\mu \mathrm{g} \mathrm{Cl}^{-1}$ $\left.\mathrm{h}^{-1}\right)$ and BPL $\left(\sim 2.5 \mu \mathrm{g} \mathrm{Cl}^{-1} \mathrm{~h}^{-1}\right)$ in the AT treatment (2013) (Fig. 5A-D). In 2012, no significant differences were observed in the BP during the phytoplankton 


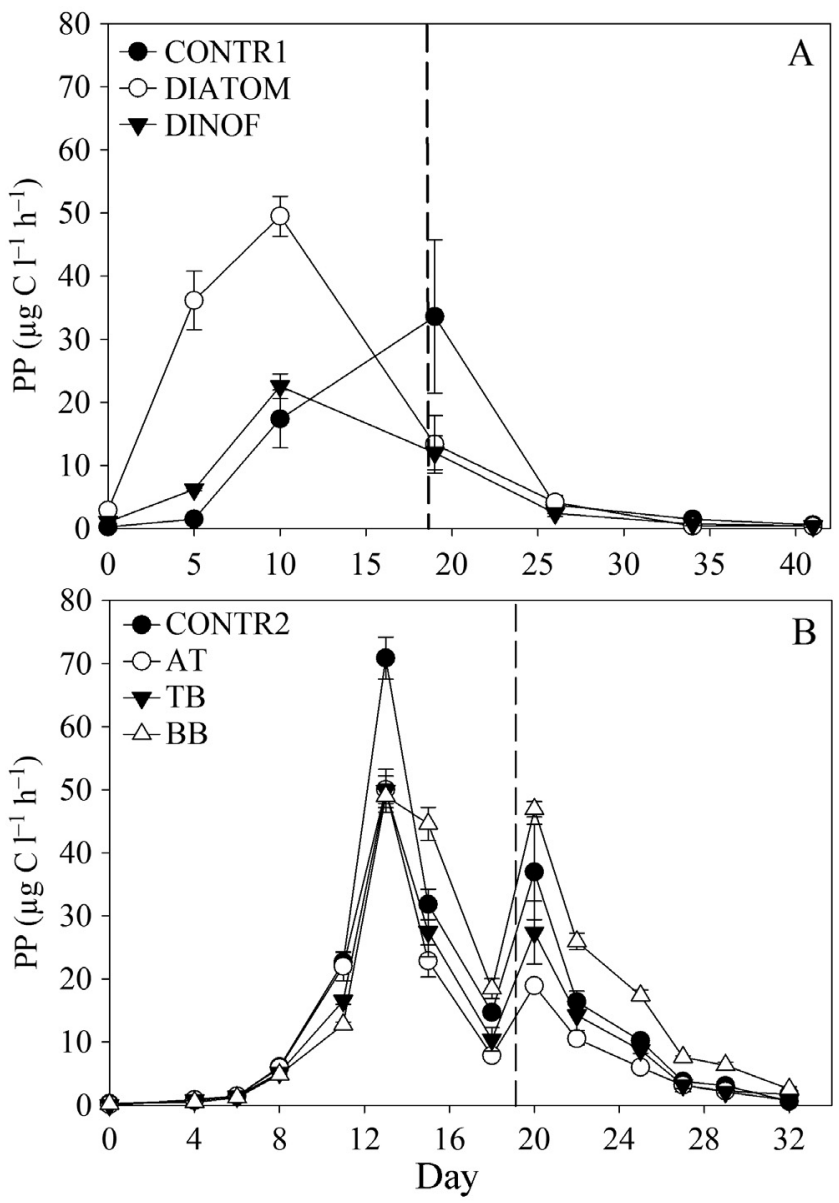

Fig. 4. Primary production (PP) (mean $\pm \mathrm{SE}, \mathrm{n}=3$ ) in (A) 2012 and (B) 2013. Dashed lines indicate the shift in temperature from 4 to $10^{\circ} \mathrm{C}$. Abbreviations as in Fig. 3

bloom phase, but there was a difference during the bacterial bloom phase (Table S1). The BP was significantly higher in the DIATOM treatment than in the CONTR1 and DINOF treatments during the bacterial bloom phase (Tukey's $b$, BPT and BPL $\mathrm{p}<0.05$ ). The differences between the CONTR1 and DINOF treatments were statistically significant for BPL (Tukey's $b$, $\mathrm{p}<0.05$ ), but not for BPT (Tukey's $b, \mathrm{p}>0.005$ ). In 2013, the BP differed significantly between treatments already in the phytoplankton bloom phase (Table S1). BP was significantly higher in the AT treatment than in the CONTR2 and BB treatments (Tukey's $b$, BPT and BPL $\mathrm{p}<0.05$ ). The BP was second highest in the TB treatment, but no significant differences were found between the TB and the other treatments (Tukey's $b, \mathrm{p}>0.05$ ). During the bacterial bloom phase, the BP also differed significantly between treatments (Table S1): it was significantly higher in the AT treatment and significantly lower in the $\mathrm{BB}$ treatment than in the CONTR2 treatment
(Tukey's $b$, BPT-L $\mathrm{p}<0.05$ ), whereas the BPT levels in the TB and CONTR2 treatments were similar (Tukey's $b$, BPT $\mathrm{p}>0.05$ ). The BPL was also similar in the AT and TB treatments (Tukey's $b$, BPL p > 0.05).

The Leu:TdR incorporation ratio was different in both years (Fig. 5E,F). In 2012, the ratio remained relatively constant in the CONTR1 and DINOF treatments at $\sim 7-13$, whereas in the DIATOM treatment the Leu:TdR ratio was more variable, reaching a value of $\sim 25$ on Days 19 and 35 (Fig. 5E). In 2013, the Leu:TdR ratio increased in all treatments at the start of the experiment, reaching a peak of $\sim 25$ on Day 6 and then dropping to $\sim 15$ on Day 8 (Fig. 5F). Later, the Leu:TdR ratio fluctuated in each treatment and decreased toward the end of the experiment.

\section{Bacterial abundance}

The response of the BA during the phytoplankton bloom phase differed, depending on the year: in 2012 it increased, whereas in 2013 it decreased. However, during the bacterial bloom phase, the BA increased in most of the treatments in both years (Fig. 6).

In 2012, the BA peaked on Day $24\left(\sim 7 \times 10^{6}\right.$ cells $\mathrm{ml}^{-1}$ ) in the DIATOM treatment and decreased thereafter, whereas in the CONTR1 treatment the BA increased throughout the experiment, with highest values on Day 41 (Fig. 6A). In the DINOF treatment, the BA increased only slightly (Fig. 6A). During the phytoplankton bloom phase, no significant differences were found between the treatments (Table S1), whereas in the bacterial bloom phase, the BA showed significant differences between treatments (Table S1), but no significant differences were found in the post hoc test (Tukey's $b, \mathrm{p}>0.05$ ).

In 2013, the BA decreased at the end of the phytoplankton bloom phase, but increased in all the treatments after the temperature was increased to $10^{\circ} \mathrm{C}$ (Fig. 6B). No significant differences were found during the phytoplankton bloom phase, whereas in the bacterial bloom phase, the treatments differed significantly (Table S1). The highest BA was observed in the AT treatment $\left(\sim 3 \times 10^{6}\right.$ cells $\left.\mathrm{ml}^{-1}\right)$ on Day 32, which was approximately half of the abundance of the year before. In contrast, the lowest BA was observed in the BB treatment (maximum $1.5 \times 10^{6}$ cells $\mathrm{ml}^{-1}$ ). The BA in the AT treatment was significantly higher than in the TB and BB treatments (Tukey's $b$, $\mathrm{p}<0.05$ ), but similar to the CONTR2 treatment (Tukey's $b, \mathrm{p}>0.05$ ). The BA was significantly lower in the BB treatment than in the CONTR2 (Tukey's $b$, $\mathrm{p}<0.05$ ). 

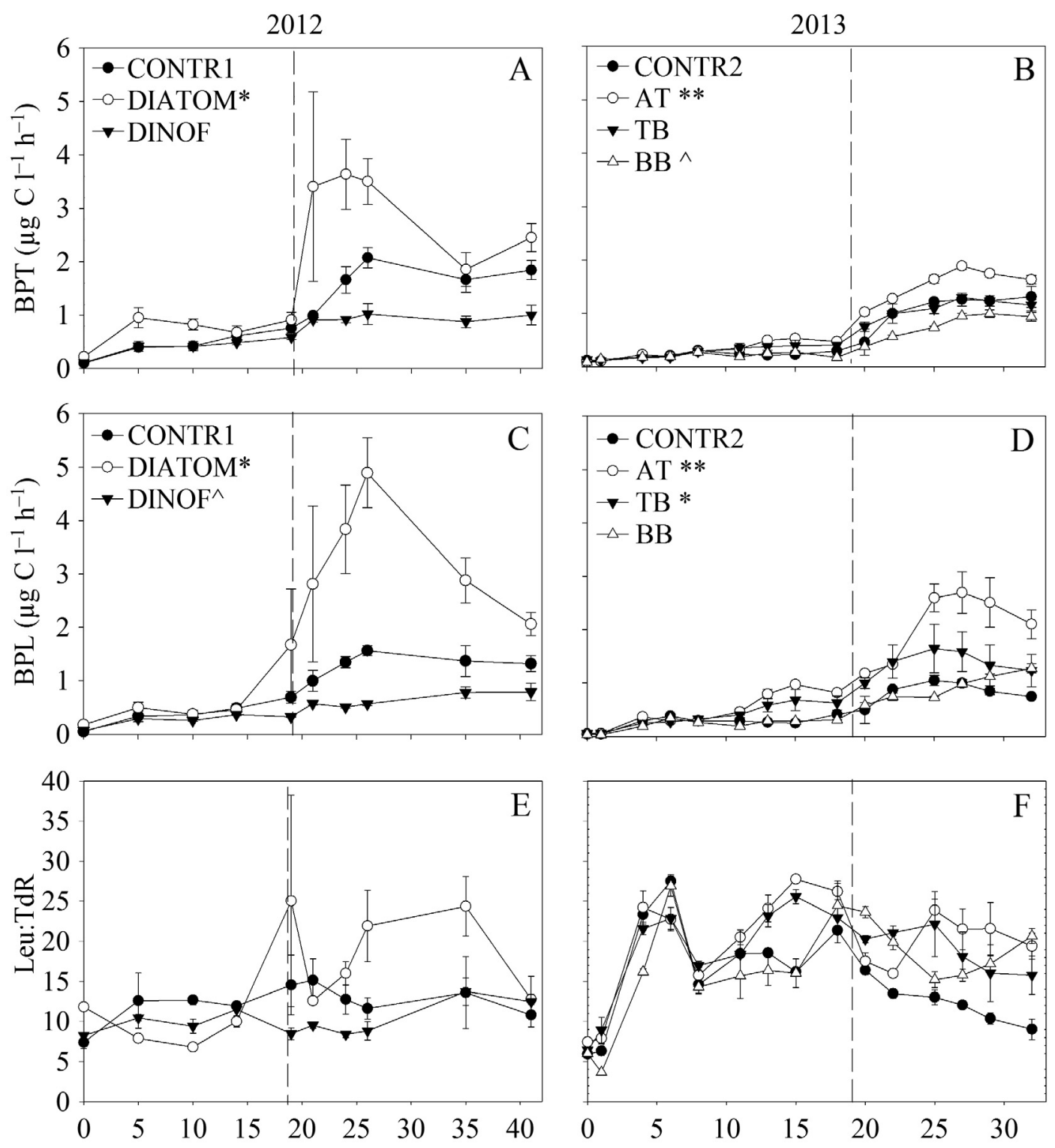

Day

Fig. 5. Bacterial production (mean $\pm \mathrm{SE}, \mathrm{n}=3$ ) measured as thymidine $(\mathrm{TdR})$ and leucine (Leu) incorporation (BPT and BPL, respectively) and the Leu:TdR incorporation ratio in $(\mathrm{A}, \mathrm{C}, \mathrm{E}) 2012$ and $(\mathrm{B}, \mathrm{D}, \mathrm{F}) 2$ 2013. Symbols $\left({ }^{*},{ }^{\wedge}\right)$ indicate treatments with significant differences (Tukey's $b, \mathrm{p}<0.05)$, higher $\left({ }^{*}\right)$ and lower $\left({ }^{\wedge}\right)$, compared with the controls (CONTR1 and CONTR2 for 2012 and 2013, respectively). One symbol indicates significant differences in the bacterial bloom phase, 2 symbols indicate significant differences in both the phytoplankton and bacterial bloom phases. Dashed lines indicate the shift in temperature from 4 to $10^{\circ} \mathrm{C}$. Abbreviations as in Fig. 3

\section{Bacterial community dynamics and composition}

The NMDS plots showed that the bacterial community dynamics were structured by the various treatments, becoming more dissimilar with time (Fig. $7 \mathrm{~A}, \mathrm{~B})$. At the start of the experiments, the bacterial communities in the water collected were similar in 2012 and 2013 (Figs. 7A,B \& 8A,B): Alphaproteobacteria (SAR11 and family Rhodobactera- ceae) dominated the community ( $50 \%$ of the OTUs), while Actinobacteria (hgcl clade) and Acidimicrobiia (CL500-29 marine group) were the second most common classes, constituting $\sim 10$ and $\sim 13 \%$ of the OTUs, respectively. The relative abundance of the class Gammaproteobacteria was higher in 2013 than in 2012, with dominance of the genera Methylobacter $(\sim 7 \%)$ and Pseudomonas ( 3\%), which were absent in 2012 . 


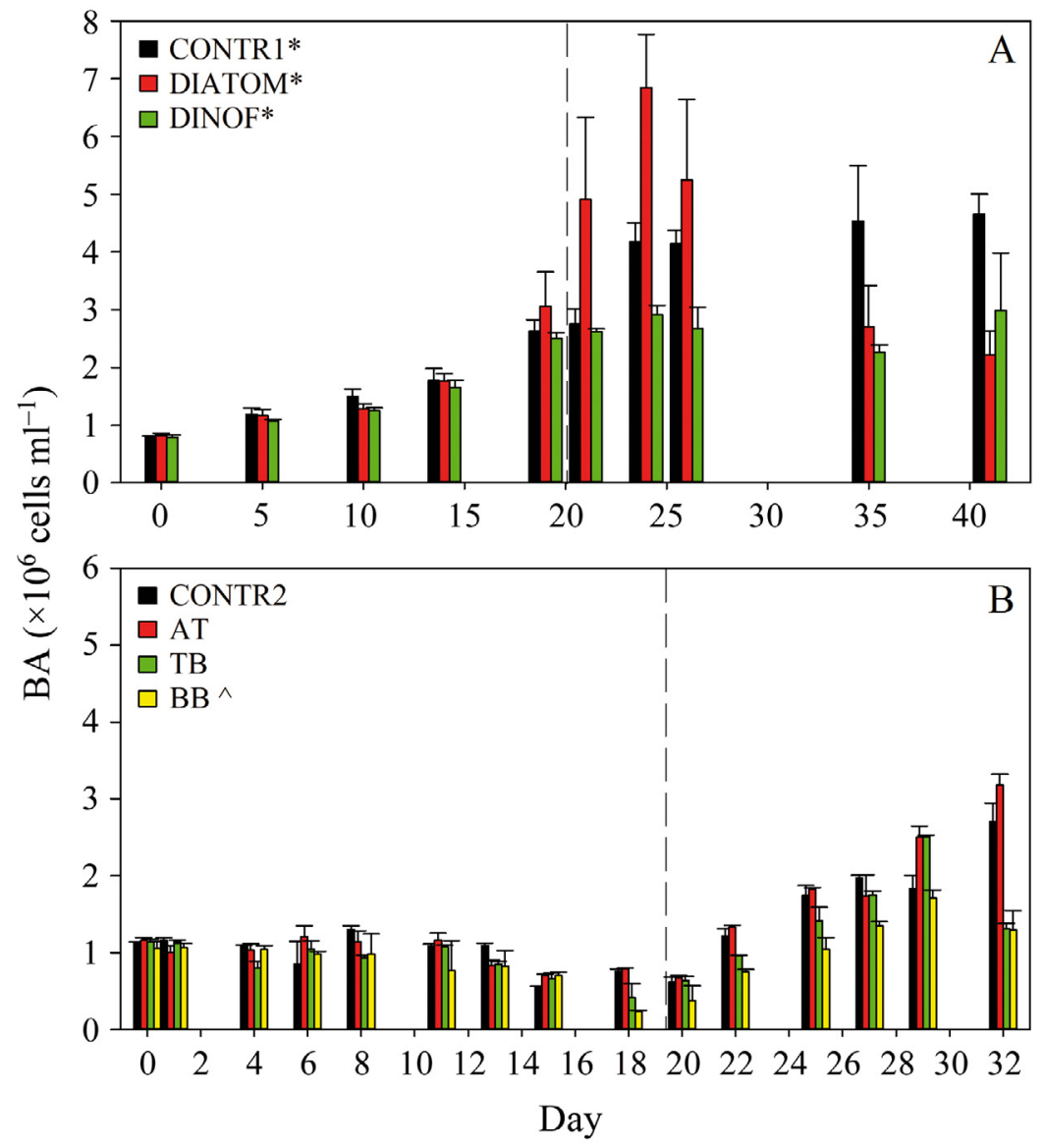

Fig. 6. Bacterial abundance (BA, mean $\pm \mathrm{SE}, \mathrm{n}=3$ ) during the experiments in (A) 2012 and (B) 2013. Symbols $\left({ }^{*},{ }^{\wedge}\right)$ indicate treatments with significant differences $(p<0.05)$ in the bacterial bloom phase. The results are based on ANOVA $\left({ }^{*}\right)$ and Tukey's test $\left({ }^{\wedge}\right)$ compared with the controls (CONTR1 and CONTR2 for 2012 and 2013, respectively). Dashed lines indicate the shift in temperature from 4 to $10^{\circ} \mathrm{C}$. Abbreviations as in Fig. 3
In 2012, the succession pattern in the DIATOM treatment differed from those in the CONTR1 and the DINOF treatments throughout the experiment (Figs. 7A \& 8A), but no statistical tests were conducted, due to the lack of replicates. The class Flavobacteriia dominated the bacterial community during the chl a peak. In the DIATOM treatment, the genus Flavobacterium constituted $\sim 43 \%$ of the total relative abundance, whereas in the CONTR1 and DINOF treatments, Flavobacterium and the NS3a marine group constituted $\sim 34$ and $28 \%$, respectively, of the relative abundance. By the end of the experiment (Day 41), the class Betaproteobacteria (genus Hydrogenophaga $\sim 20 \%$ of the OTUs) increased in the DIATOM treatment, whereas in the CONTR1 and DINOF treatments, the alphaproteobacterial (SAR11) predominance was reverted, accompanied by an increase in the proportion of Cyanobacteria (genus Synechococcus $\sim 10 \%$ ). In addition, the relative abundance of the class Actinobacteria (genus Candidatus Aquiluna) increased in all the treatments towards the end of the experiment, especially in the CONTR1 and DINOF treatments (genus hgcl clade). Within the
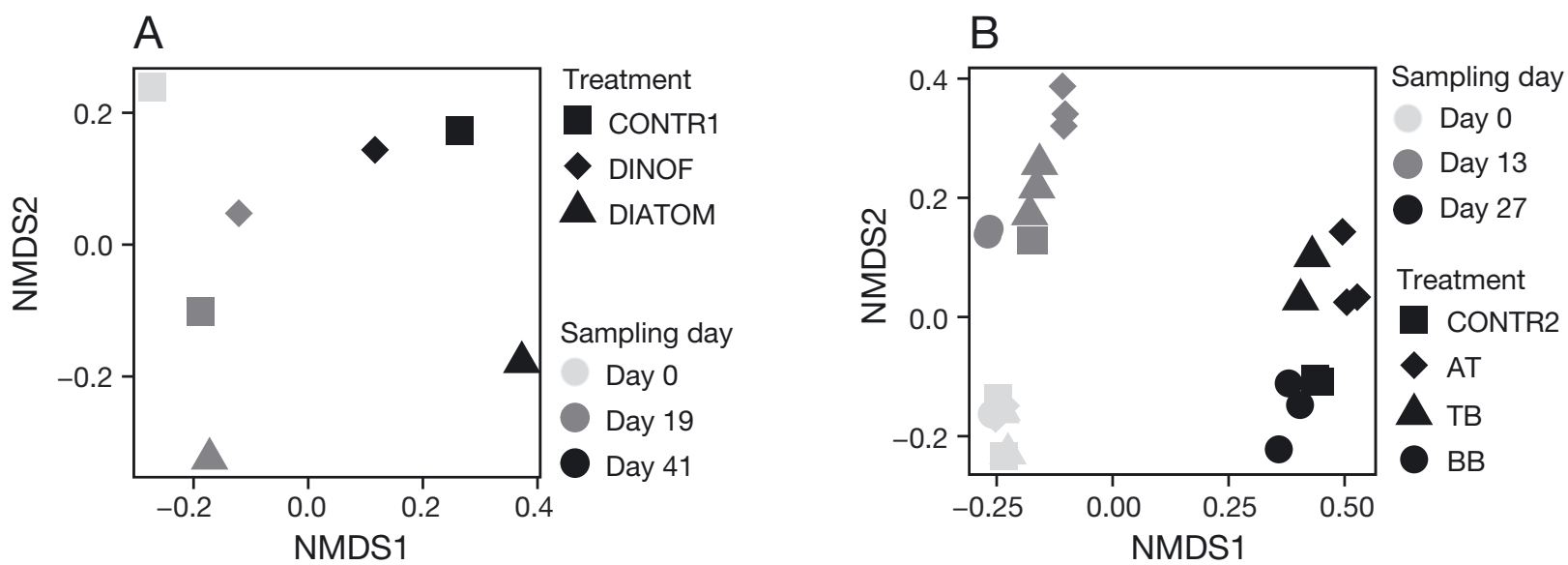

Fig. 7. Nonmetric multidimensional scaling (NMDS) plots of the bacterial community composition on the 3 sampling days (A) in 2012: Day 0 (start), Day 19 (chl a peak), and Day 41 (end); and (B) in 2013: Day 0 (start), Day 13 (chl a peak), and Day 27 (bacterial production peak). Abbreviations as in Fig. 3. There was no replication in $2012(\mathrm{n}=1)$ and replicate samples were collected in $2013(n=3)$. Stress values are 0.019 in 2012 and 0.046 in 2013 

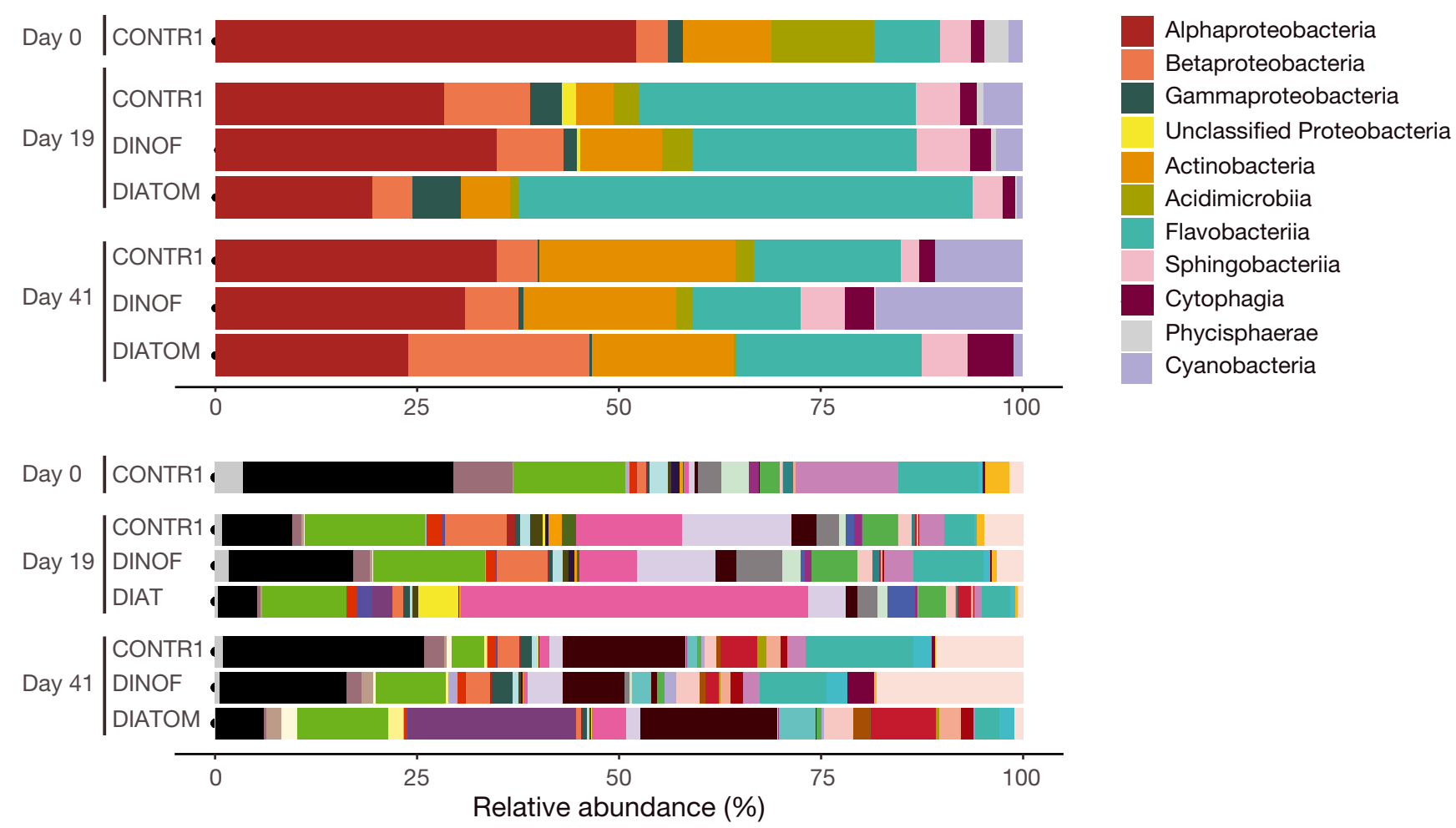

Alphaproteobacteria:Candidatus Pelagibacter
Alphaproteobacteria: SAR11 Chesapeake-Delaware Bay
Alphaproteobacteria:Unclassified SAR11 Surface 2
Alphaproteobacteria:Loktanella
Alphaproteobacteria:Pseudorhodobacter
Alphaproteobacteria:unclassified Rhodobacteraceae
Alphaproteobacteria:Rhodovulum
Alphaproteobacteria:Thalassobaculum
Alphaproteobacteria:Sphingorhabdus
Alphaproteobacteria:Unclassified
Betaproteobacteria:Hydrogenophaga
Betaproteobacteria:BAL58 marine group
Betaproteobacteria:Limnohabitans
Betaproteobacteria:GKS98 freshwater group
Betaproteobacteria:OM43 clade
Gammaproteobacteria:SAR92 clade
Gammaproteobacteria:Shewanella
Gammaproteobacteria:Unclassified SAR86 clade
Gammaproteobacteria:Unclassified OM182 clade
Unclassified Proteobacteria
Flavobacteriia:Flavobacterium
Flavobacteriia:NS3a marine group

Flavobacteriia:Polaribacter
Flavobacteriia:Aequorivita
Flavobacteriia:Owenweeksia
Flavobacteriia:Fluviicola
Sphingobacteriia:Pedobacter
Sphingobacteriia:Unclassified Saprospiraceae
Sphingobacteriia:Candidatus Aquirestis
Sphingobacteriia:Unclassified NS11-12 marine group
Sphingobacteriia:Unclassified LiUU 11-161
Cytophagia:Algoriphagus
Cytophagia:Leadbetterella
Cytophagia:Marinoscillum
Actinobacteria:Candidatus Aquiluna
Actinobacteria:Salinibacterium
Actinobacteria:Candidatus Limnoluna
Actinobacteria:Unclassified Microbacteriaceae
Acidimicrobiia:CL500-29 marine group
Actinobacteria:hgcl clade
Actinobacteria:Candidatus Planktophila
Actinobacteria:unclassified PeM15
Phycisphaerae:CL500-3
Cyanobacteria:Synechococcus

Fig. 8. (Above and following page.) Class- and genus-level bacterial diversity of 16S ribosomal RNA (rRNA) gene sequences $(\sim 450 \mathrm{bp})$ representing $>0.1 \%$ of all normalized operational taxonomic units (OTUs) on (A) Day 0 (start), Day 19 (chl a peak), and Day 41 (end) in 2012, and on (B) Day 0 (start), Day 13 (chl a peak), and Day 27 (bacterial production peak) in 2013. Abbreviations as in Fig. 3. No replicates were set in $2012(\mathrm{n}=1)$. Significant differences were tested in $2013(\mathrm{n}=3)$. *: treatments with significant differences (PERMANOVA, $\mathrm{p}<0.05$ ) compared to the control 

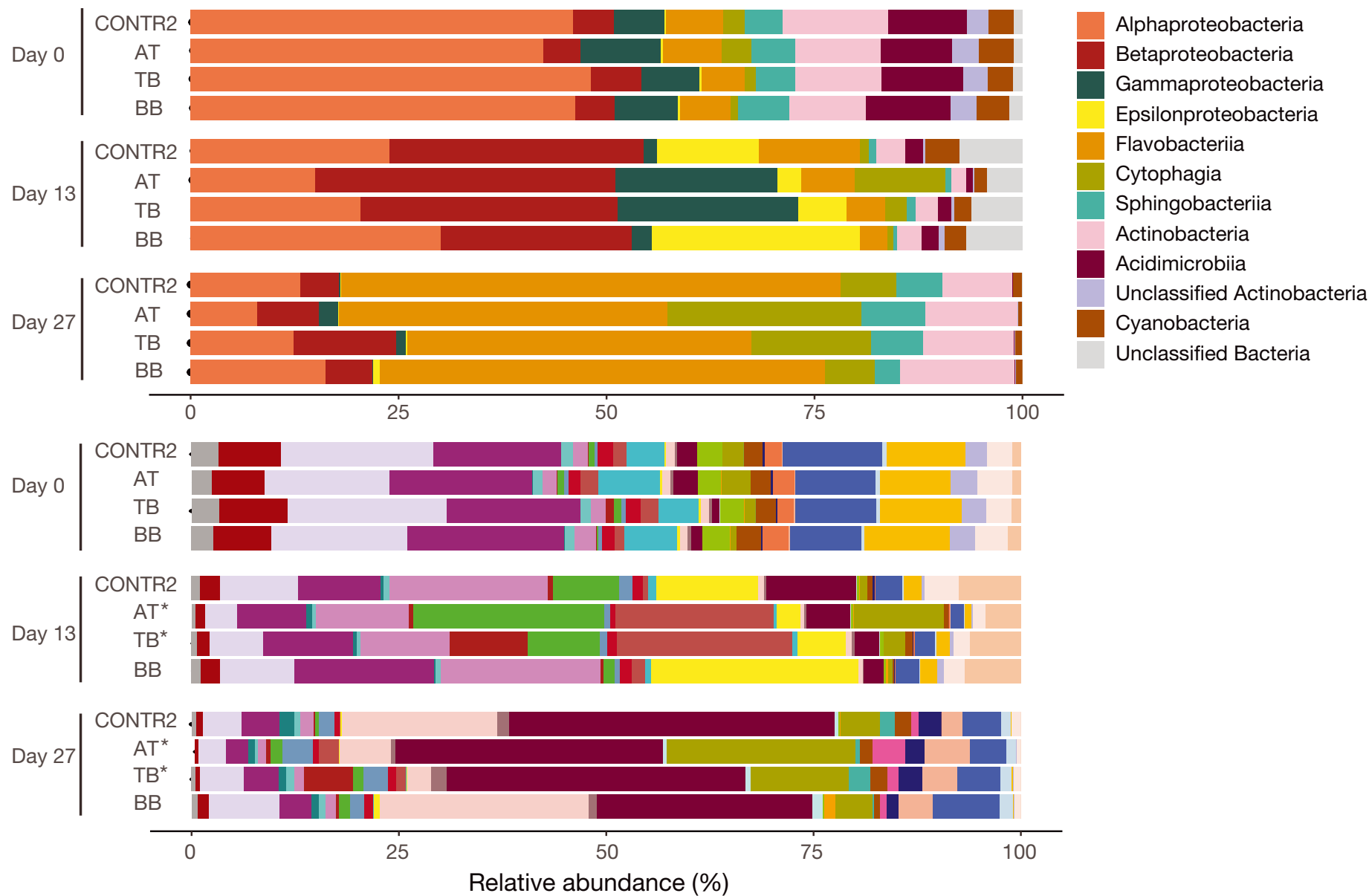

Alphaproteobacteria:Candidatus Pelagibacter

Alphaproteobacteria:unclassified SAR11 Surface 2

Alphaproteobacteria:unclassified SAR11 Chesapeake-Delaware Bay

Alphaproteobacteria:unclassified Rhodobacteraceae

Alphaproteobacteria:Pseudorhodobacter

Alphaproteobacteria:Sphingorhabdus

Betaproteobacteria:BAL58 marine group

Betaproteobacteria:Hydrogenophaga

Betaproteobacteria:Albidiferax

Betaproteobacteria:GKS98 freshwater group

Betaproteobacteria:OM43 clade

Gammaproteobacteria:Pseudomonas

Gammaproteobacteria:Methylobacter

Epsilonproteobacteria:Arcobacter

Flavobacteriia:NS3a marine group

Flavobacteriia:Polaribacter

Flavobacteriia:Flavobacterium
Flavobacteriia:Fluviicola

Flavobacteriia:Owenweeksia

Cytophagia:Leadbetterella

Cytophagia:Algoriphagus

Cytophagia:unclassified MWH-CFBk5

Sphingobacteriia:unclassified NS11-12 marine group

Sphingobacteriia:unclassified Saprospiraceae

Sphingobacteriia:Candidatus Aquirestis

Sphingobacteriia:unclassified envOPS 17

Actinobacteria:Candidatus Aquiluna

Actinobacteria:hgcl clade

Actinobacteria:Candidatus Planktophila

Acidimicrobiia:CL500-29 marine group

Unclassified Actinobacteria

Cyanobacteria:Synechococcus

Unclassified bacteria

Fig. 8 (continued)

Flavobacteriia clade, Flavobacterium and the NS3a marine group were replaced by the genus Polaribacter in all of the treatments at the end of the experiment.
In 2013, the bacterial communities were clustered (Fig. 7B) and differed significantly between treatments over time (PERMANOVA, treatment $\times$ time: df: 6 , pseudo-F: $2.41, \mathrm{p}=0.011$ ). Using pairwise tests 
for the statistical analysis of the treatments, significant differences were observed between the CONTR2 and both treatments with diatom addition (PERMANOVA, CONTR2 vs. AT: $\mathrm{p}=0.027$ and CONTR2 vs. TB: $p=0.021$ ) and between the treatments with diatom and dinoflagellate addition (PERMANOVA, TB vs. BB: $\mathrm{p}=0.006$ and AT vs. BB: $\mathrm{p}=0.013)$. No significant differences were found between the CONTR2 and the BB treatment (PERMANOVA, p > 0.05). In 2013, patterns similar to those in 2012 were observed in terms of bacterial community changes: Alphaproteobacteria (SAR11 and family Rhodobacteraceae) decreased and Flavobacteriia (Flavobacterium and the NS3a marine group) increased during the experiment in all treatments (Fig. 8B). However, in 2013, a decrease in the proportion of Flavobacteriia was not observed. Betaproteobacteria (BAL58 marine group in all of the treatments; Albidiferax in the CONTR2, AT, and TB treatments; and Hydrogenophaga in the TB treatment) exhibited transient dominance in the bacterial community (accounting for $\sim 30 \%$ of the OTUs) at the chl a peak. In addition to Betaproteobacteria, transient gammaproteobacterial (genus Pseudomonas) dominance was also observed in the AT and TB treatments ( 20\% of the OTUs), whereas Epsilonproteobacteria (genus Arcobacter) increased in the CONTR2 ( $12 \%$ of the OTUs) and BB treatments ( $25 \%$ of the OTUs). At the BP peak (Day 27), the Flavobacteriia clade predominated in all of the treatments (genus Flavobacterium $\sim 25-40 \%$ of the OTUs), and the relative abundance of the Actinobacteria clade increased again (hgcl clade and Candidatus Aquiluna). In addition to Flavobacterium, the proportion of the NS3a marine group increased in the CONTR2 and BB treatments $(\sim 18-25 \%$ of the OTUs), whereas the genus Algoriphagus (Cytophagia) increased in the AT and TB treatments ( $12-22 \%$ of the OTUs).

\section{DISCUSSION}

Two mesocosm experiments were conducted in consecutive years to determine whether the shift in phytoplankton community composition (diatom vs. dinoflagellate) affects BP, BA, and BCC. Based on the temperature setup and the inorganic nutrient concentrations, the experiments were divided into 2 different phases: the phytoplankton bloom phase, characterized by the development of autotrophic organisms with the corresponding chl a and PP peaks, and the bacterial bloom phase, characterized by the increase in bacterial growth.

\section{Phytoplankton bloom phase}

The high inorganic nutrient concentrations in the water collected and the improved light conditions initiated the phytoplankton bloom phase. The phytoplankton community composition in the water collected was largely formed by diatom species in both years. The addition of the cultures shifted the naturally occurring phytoplankton community; the diatom and dinoflagellate species added predominated in 2012 (Dia:Dino index $=0.95$ and 0.15, respectively), but not in 2013 (Dia:Dino index 0.69-1.00), likely because the inoculum was 3.5-fold higher in 2012 than in 2013. This higher addition in 2012 promoted the more rapid development of the phytoplankton bloom in the DIATOM and DINOF treatments than in the CONTR1 treatment and resulted in increased variation between the replicates in the DIATOM treatment.

The dominant cold-water diatoms in the Baltic Sea generally have higher maximum growth rates than competing dinoflagellates (Spilling \& Markager 2008). However, dinoflagellates can dominate the phytoplankton community when their initial cell abundance is high enough to build up bloom-level biomass before the diatoms catch up (Kremp et al. 2008). This is what occurred in our DINOF treatment in 2012; the inocula of the dinoflagellate cultures were high enough to retain the dominance throughout the phytoplankton bloom phase. Ice thickness and stratification patterns are other crucial factors affecting dinoflagellate development in the natural environment (Klais et al. 2013), but this was not considered in our experimental setup. In 2013, the naturally occurring (not added) diatom Thalassiosira levanderi predominated in all the treatments, even in the $\mathrm{BB}$ treatment (Dia:Dino index $=0.69$ ), despite having a biomass lower than that of the other diatom species initially and the maximum growth rate being similar to that of the diatoms added (Spilling 2007). T. levanderi is typically abundant during the initial phase of the spring bloom (Wasmund et al. 1998), forming dense blooms under the ice (Arrigo et al. 2012). This species probably benefitted from being acclimated to the initial water conditions at the start of the experiment and managed to increase its relative abundance, compared with competing phytoplankton.

The phytoplankton bloom phase ended with the depletion of nitrate, which is typical of this N-limited region of the Baltic Sea (Tamminen \& Andersen 2007). The collapse of phytoplankton blooms is typically followed by an increase in bacterial activity and 
BA (Riemann et al. 2000, Fandino et al. 2001, Buchan et al. 2014), which was also observed in our experiments. Primary producers provide an adequate environment for bacterial assemblages, since phytoplankton cells release DOM, which fuels bacterial growth and promotes the coupling between phytoplankton and bacteria (Biddanda \& Benner 1997, Buchan et al. 2014, Bunse \& Pinhassi 2017). We observed this bacteria-phytoplankton coupling, but with a time lag of $1 \mathrm{wk}$, most likely due to the carbon limitation and the low temperature $\left(4^{\circ} \mathrm{C}\right)$ in our experiments during the phytoplankton bloom phase. In addition, the BA decreased towards the end of this phase in 2013, which could have been caused by competition with phytoplankton cells for inorganic nutrients (Buchan et al. 2014) or increased grazing pressure. Furthermore, high grazing pressure was observed on bacterioplankton at low temperatures in an experiment by von Scheibner et al. (2014). Low temperature, inorganic and organic nutrient limitation, and grazing pressure are crucial factors regulating bacterial growth (Lignell et al. 1993, Lindh et al. 2013, Bunse et al. 2016). Grazing pressure on phytoplankton is low during the spring bloom in the Baltic Sea (Lignell et al. 1993). However, grazing can control the bacterial biomass following the spring bloom (Lignell et al. 1992). In our experiments, we found a clear increase in BA following the phytoplankton bloom phase, suggesting that the grazing pressure at that time did not prevent bacterial biomass growth.

Depending on the growth rate and/or physiological status of the bacterial assemblage, the bacteria invest their cellular resources in either cell division (TdR incorporation) or biomass synthesis and/or maintenance costs (Leu incorporation) (Chin-Leo \& Kirchman 1990, Hoppe et al. 2006). The unfavorable conditions of low temperature and chl a are often characterized by over $10 \times$ higher Leu incorporation than TdR incorporation (Shiah \& Ducklow 1997). In 2013, we observed an increase in the Leu:TdR ratio at the start of the experiment, suggesting that increased Leu incorporation was channeled to maintenance, which decreased again after the chl a began to increase, most likely reflecting higher carbon availability.

Despite the unfavorable conditions in 2013, there was a significant increase in BP in the AT treatment during the phytoplankton bloom phase. There were also changes in the BCC that were already observed at the chl a peak in both years. The bacterial community was dominated initially by Alphaproteobacteria (SAR11 and family Rhodobacteraceae), which commonly occur under pre-bloom conditions (Andersson et al. 2010, Herlemann et al. 2011, Laas et al. 2015). During the phytoplankton bloom phase, the alphaproteobacterial predominance changed to flavobacteriial predominance (Flavobacterium and/or the NS3a marine group) in 2012, whereas in 2013 the community changed to beta- and gammaproteobacterial predominance (Albidiferax and the BAL58 marine group-Pseudomonas) in the AT and TB treatments and to beta- and epsilonproteobacterial predominance (BAL58 marine group-Arcobacter) in the BB and CONTR2 treatments. Both Flavobacteriia and Gammaproteobacteria are common groups during and/or after phytoplankton blooms (Teeling et al. 2012, Laas et al. 2015, Bunse et al. 2016), and the most abundant genera within these classes (Flavobacterium and Pseudomonas) are associated with diatom blooms (Amin et al. 2012). Flavobacteriia are able to degrade complex HMW substrates (Cottrell \& Kirchman 2000, Kirchman 2002, Buchan et al. 2014), whereas Gammaproteobacteria are opportunistic bacteria that are able to exploit elevated concentrations of LMW substrates (Eilers et al. 2000, Pinhassi \& Berman 2003, Gómez-Consarnau et al. 2012). The bacterial community patterns observed in Flavobacteriia and Gammaproteobacteria indicate resource partitioning consistent with previous studies (Teeling et al. 2012). However, Gammaproteobacteria, as is typical for copiotrophs, may behave as generalists, due to their capability for using various algal-derived DOC sources (Sarmento et al. 2016) and enrichment treatments (Teira et al. 2010). Betaproteobacteria are similar to Gammaproteobacteria in their DOM consumption (Cottrell \& Kirchman 2000, Hoikkala 2012 and references therein) and are positively associated with increased DOC concentrations in estuarine environments (Bouvier \& del Giorgio 2002).

The treatments with diatom additions likely produced ample amounts of labile substrates, boosting bacterial growth and causing the pronounced flavobacteriial predominance in the DIATOM treatment in 2012, as well as a peak in Gamma- and Betaproteobacteria in 2013. Gammaproteobacteria may also have occurred in 2012, but the peak may have been missed, due to the long gap between sampling days (Days 0 and 19).

\section{Bacterial bloom phase}

The high phytoplankton biomass in the phytoplankton bloom phase and the increase in temperature to $10^{\circ} \mathrm{C}$ after nutrient depletion were the main 
triggers for the development of the bacterial bloom phase following the chl a peak. There was a more pronounced effect of the phytoplankton community composition on bacterial activity during the bacterial bloom phase than in the phytoplankton bloom phase.

The BP was significantly higher in the treatments with diatom addition (DIATOM, AT, TB-BPL) and lower in the treatments with dinoflagellate addition (DINOF-BPL, BB-BPT) than in the treatments with no addition (CONTR1 and CONTR2). Thus, the treatments with diatom addition fueled the bacterial growth more efficiently than the treatments with dinoflagellate addition, even before the collapse of the phytoplankton bloom (AT treatment, Fig. 4B in 2013).

In 2012, the inoculum in the DIATOM treatment was larger than in the DINOF treatment and, thus, the PP and total phytoplankton carbon biomass were greater in the DIATOM treatment, suggesting increased carbon fixation in this treatment, compared with the CONTR1 and DINOF treatments. The DOC concentration (Fig. 3A) was slightly higher in the DIATOM treatments than in the DINOF and CONTR1 treatments, but this result was not unambiguous $(\mathrm{p}=0.055)$. The DIATOM treatment was dominated by Chaetoceros sp. This taxon releases higher concentrations of DOM, measured as percentage of extracellular release (Wetz \& Wheeler 2007), and also produces more extracellular polysaccharides than other diatom species (Myklestad 1995), enhancing bacterial activity (Lekunberri et al. 2012, Sarmento \& Gasol 2012). The DOM released in the DIATOM treatment was likely translated into 2 -fold higher BP, since diatoms can produce highly labile substrates, such as polysaccharides (Myklestad 2000).

In 2013, we investigated whether smaller changes (lower concentrations of culture addition) in the phytoplankton community produce similar effects in the bacterial community. In that year, the $\mathrm{chl} a$ and first PP peaks were higher than in 2012, but this could have been due to the higher sampling frequency than in 2012. We also observed a second PP peak in 2013, most likely a sign of DOM utilization by the bacterioplankton and consequent nutrient remineralization, which can boost phytoplankton carbon fixation (Sarmento \& Gasol 2012, Bunse et al. 2016). However, the chl a peak and second PP production peak were highest in the $\mathrm{BB}$ treatment, which resulted in the lowest $\mathrm{BP}$, the lowest $\mathrm{BA}$, and also presented a significant delay in the DON utilization, compared with the other treatments. This decoupling between PP and BP in this treatment could have been due to a specific response of the bacterial activity to the DOM by the present phytoplankton community, or alternatively to competition for inorganic nutrients with phytoplankton cells (Sebastián \& Gasol 2013, Buchan et al. 2014, Landa et al. 2014). There were also clear differences between the treatments with diatom additions (AT and TB), also suggesting differences in the bacterial response between different diatom-dominated communities, perhaps driven by species-specific release of DOM.

We observed no significant differences in the DOC concentrations between treatments, suggesting rapid turnover and incorporation of the carbon released into the bacterial biomass, which is supported by the difference in BA. The labile DOC release by the algae was quickly taken up by the bacterioplankton, which would explain why there was no quantitative effect of the phytoplankton community on the DOC pool. Another factor is the very high concentration of DOC in the Baltic Sea $\left(6-8 \mathrm{mg} \mathrm{l}^{-1}\right)$, which is caused by the high input of terrestrially derived organic matter (Hoikkala et al. 2015). Any difference in the DOC concentration caused by phytoplankton would have been difficult to detect against this large background signal.

There could also have been other mechanisms affecting bacterial activity. In 2013, the dominant species in both the CONTR2 and BB treatments was the diatom T. levanderi ( $\sim 50$ and $\sim 40 \%$ of the biomass, respectively), which presumably produced and released DOM relative to its biomass. However, BA was significantly lower in the BB treatments than in the CONTR2 treatment, a difference that was larger than what could have been expected from the relatively small biomass of Biecheleria baltica in the BB treatment (Fig. 6). This suggests an indirect effect of $B$. baltica on bacterial activity other than lower quantity/quality of the DOM release. Dinoflagellates produce and release a range of compounds with inhibitory effects on other planktonic organisms (e.g. allelochemicals or toxins; Granéli \& Hansen 2006), which may also have antibacterial effects (Trick et al. 1984). Alternatively, bacterial loss processes, such as grazing, could have been elevated in the BB treatment, since many dinoflagellates are mixotrophic, consuming food particles in addition to fixing carbon through photosynthesis (Jeong et al. 2010). Further studies are required to disentangle any indirect effect of $B$. baltica on the bacterial community. In addition, a major proportion $(\sim 50 \%$ in 2012 and $\sim 30 \%$ in 2013) of the POC was removed by taking out the settling material, but there was no difference in the amount of biomass removed between the treatments, so this could not explain the large difference 
in bacterial activity between treatments. Disintegration or lysis of dinoflagellate vegetative cells can be a major loss process in a natural environment (Heiskanen 1998), but we observed no dinoflagellate cells lysing, which would likely have increased BP.

The bacterial community dynamics during the bacterial bloom phase differed between 2012 and 2013. In 2012, the predominance of Flavobacteriia during the chl a peak was reverted back to alphaproteobacterial predominance, whereas in 2013 Flavobacteriia predominated in all treatments, with more than $50 \%$ of the OTUs. In addition, a shift within the Flavobacteriia clade was observed in both years with the occurrence of Flavobacterium, the NS3a marine group, and Polaribacter. A similar succession pattern was previously observed in the North Sea (Teeling et al. 2016). Polaribacter is a recurrent genus in the Baltic Sea during phytoplankton blooms (Laas et al. 2015, Bunse et al. 2016), while the NS3a marine group (and Flavobacteriia in general) have been observed during dinoflagellate blooms (Fandino et al. 2001, Yang et al. 2015).

Further differences between treatments were observed in both years. In 2012, the proportion of Betaproteobacteria (genus Hydrogenophaga) increased in the DIATOM treatment, whereas in the CONTR1 and DINOF treatments, increased numbers of actinobacterial and cyanobacterial groups were observed during the experiment. In 2013, the proportion of the genus Algoriphagus (Cytophagia) increased in the AT and TB treatments, differing significantly from the CONTR2 and BB treatments. This genus may assimilate N-acetyl glucosamide, a monosaccharide that probably increases during the decay of the diatom blooms (Cottrell \& Kirchman 2000, Eckert et al. 2012). The proportion of Actinobacteria (hgcl clade and Candidatus Aquiluna) increased towards the end of the experiment in this year. Actinobacteria is a common clade observed in the Baltic Sea, due to the low salinity. They are considered slow-growing and predator-resistant (Eckert et al. 2012), and are associated with decaying phytoplankton blooms and Cyanobacteria-derived DOC (Stepanauskas et al. 2003, Hugerth et al. 2015, Bunse et al. 2016).

The distinct occurrence and predominance of the main bacterial taxa (Flavobacteriia, Beta- and Gammaproteobacteria, Actinobacteria) in our experiments could have been due to the difference in sampling days in both years: in 2012, the bacterial community was collected at the end of the experiment (Day 41) and in 2013 at the BP peak (Day 27). Thus, we probably captured different stages of the phytoplankton bloom development. The bacterial communities in the various treatments with diatom additions also became more dissimilar than their respective controls and treatments with dinoflagellate additions. Thus, the composition and/or the quantity of the DOM released may have differed not only between years, but also between the phytoplankton species present in the various treatments. An indication of the differences in quality of the DOM released can be seen in our experiment of 2013, in which we found significant differences between the BB treatment and CONTR2 in the DON concentration, as well as in BPT. However, we found no significant differences in the BCC between the CONTR2 and BB treatment. Shifts in the bacterioplankton composition may be caused by changes in the quality of the DOM (Pinhassi et al. 2004, Landa et al. 2016), but the quantity of the released DOM may also be important (Sarmento et al. 2016). We can make no further conclusions about this topic, based on our data, because we did not characterize the DOM pool in detail.

Nevertheless, the increase in bacterial activity during the bacterial bloom phases and the increased relative abundance of bacteria associated with phytoplankton blooms (Flavobacteriia, Beta- and Gammaproteobacteria) revealed a link between ecosystem functioning and diversity. These results confirm the importance of the proper identification of the phytoplankton community, due to their differences in the quality and quantity of the DOM released (Bunse et al. 2016, Kirchman et al. 2017).

\section{CONCLUSIONS}

The differences in the bacterioplankton, in terms of $\mathrm{BP}, \mathrm{BA}$, and BCC, in our study were clearly driven by the phytoplankton community composition. The presence of the various phytoplankton species likely produced differences in the quality and/or quantity of the DOM pool, which affected bacterial physiology and the BCC. In particular, the diatom-dominated communities were characterized by higher BA and $\mathrm{BP}$ and differed in BCC, suggesting that the diatomdominated communities excreted more carbon than the communities with a co-occurrence of dinoflagellates. The results suggest that the long-term shift towards higher dinoflagellate abundance during the spring bloom in the Baltic Sea may cause reduction in $\mathrm{BP}$ and changes in the $\mathrm{BCC}$, which may reduce pelagic remineralization of organic matter and alter the material fluxes in the microbial loop. 
Acknowledgements. This study was funded by the Walter and Andrée de Nottbeck Foundation, the Academy of Finland (decision numbers 259164 and 292711) and the Spanish Ministry of Economy and Competitiveness (CTM201459345-R) within the National Plan for Scientific and Technical Research and Innovation 2013-2016. We thank the staff at Tvärminne Zoological Station for help with the analytical measurements and sampling during the experiments. Dr. Anke Kremp is acknowledged for providing the inoculum cultures.

\section{LITERATURE CITED}

Amin SA, Parker MS, Armbrust EV (2012) Interactions between diatoms and bacteria. Microbiol Mol Biol Rev 76:667-684

Amon RM, Benner R (1996) Bacterial utilization of different size classes of dissolved organic matter. Limnol Oceanogr 41:41-51

Anderson MJ (2001) A new method for non-parametric multivariate analysis of variance. Austral Ecol 26:32-46

Anderson MJ (2006) Distance-based tests for homogeneity of multivariate dispersions. Biometrics 62:245-253

Anderson M, Gorley R, Clarke K (2008) PERMANOVA+ for PRIMER: guide to software and statistical methods. PRIMER-E, Plymouth

Andersson A, Haecky P, Hagström A (1994) Effect of temperature and light on the growth of micro- nano- and pico-plankton: impact on algal succession. Mar Biol 120: 511-520

Andersson AF, Riemann L, Bertilsson S (2010) Pyrosequencing reveals contrasting seasonal dynamics of taxa within Baltic Sea bacterioplankton communities. ISME J 4: 171-181

Arrigo KR, Perovich DK, Pickart RS, Brown ZW and others (2012) Massive phytoplankton blooms under Arctic sea ice. Science 336:1408

auf dem Venne H (1994) Zur Verbreitung und ökologischen Bedeutung planktischer Ciliaten in zwei verschiedenen Meeresgebieten: Grönlandsee und Ostsee. PhD thesis, Christian Albrechts Universität, Kiel

Azam F, Fenchel T, Field JG, Gray JS, Meyer-Reil LA, Thingstad F (1983) The ecological role of water-column microbes in the sea. Mar Ecol Prog Ser 10:257-263

Baines SB, Pace ML (1991) The production of dissolved organic matter by phytoplankton and its importance to bacteria: patterns across marine and freshwater systems. Limnol Oceanogr 36:1078-1090

* Benner R, Von Bodungen B, Farrington J, Hedges J and others (1993) Measurement of dissolved organic carbon and nitrogen in natural waters: workshop report. Mar Chem 41:5-10

Biddanda B, Benner R (1997) Carbon, nitrogen, and carbohydrate fluxes during the production of particulate and dissolved organic matter by marine phytoplankton. Limnol Oceanogr 42:506-518

Bouvier TC, del Giorgio PA (2002) Compositional changes in free-living bacterial communities along a salinity gradient in two temperate estuaries. Limnol Oceanogr 47:453-470

Buchan A, LeCleir GR, Gulvik CA, González JM (2014) Master recyclers: features and functions of bacteria associated with phytoplankton blooms. Nat Rev Microbiol 12: 686-698

Bunse C, Pinhassi J (2017) Marine bacterioplankton sea- sonal succession dynamics. Trends Microbiol 25:494-505

*Bunse C, Bertos-Fortis M, Sassenhagen I, Sildever S and others (2016) Spatio-temporal interdependence of bacteria and phytoplankton during a Baltic Sea spring bloom. Front Microbiol 7:517

Castillo CR, Sarmento H, Álvarez-Salgado XA, Gasol JM, Marraséa C (2010) Production of chromophoric dissolved organic matter by marine phytoplankton. Limnol Oceanogr 55:446-454

* Chin-Leo G, Kirchman DL (1990) Unbalanced growth in natural assemblages of marine bacterioplankton. Mar Ecol Prog Ser 63:1-8

* Chung J, Ha ES, Park HR, Kim S (2004) Isolation and characterization of Lactobacillus species inhibiting the formation of Streptococcus mutans biofilm. Oral Microbiol Immunol 19:214-216

Clarke K, Gorley R (2006) PRIMER v6: user manual/tutorial. Primer-E, Plymouth

Cole JJ, Findlay S, Pace ML (1988) Bacterial production in fresh and saltwater ecosystems: a cross-system overview. Mar Ecol Prog Ser 43:1-10

* Cottrell MT, Kirchman DL (2000) Natural assemblages of marine proteobacteria and members of the CytophagaFlavobacter cluster consuming low-and high-molecularweight dissolved organic matter. Appl Environ Microbiol 66:1692-1697

* Eckert EM, Salcher MM, Posch T, Eugster B, Pernthaler J (2012) Rapid successions affect microbial N-acetylglucosamine uptake patterns during a lacustrine spring phytoplankton bloom. Environ Microbiol 14:794-806

Edgar RC (2013) UPARSE: highly accurate OTU sequences from microbial amplicon reads. Nat Methods 10:996-998

Edgar RC, Haas BJ, Clemente JC, Quince C, Knight R (2011) UCHIME improves sensitivity and speed of chimera detection. Bioinformatics 27:2194-2200

Edwards U, Rogall T, Blöcker H, Emde M, Böttger EC (1989) Isolation and direct complete nucleotide determination of entire genes. Characterization of a gene coding for 16S ribosomal RNA. Nucleic Acids Res 17:7843-7853

Eilers H, Pernthaler J, Glöckner FO, Amann R (2000) Culturability and in situ abundance of pelagic bacteria from the North Sea. Appl Environ Microbiol 66:3044-3051

Fandino LB, Riemann L, Steward GF, Long RA, Azam F (2001) Variations in bacterial community structure during a dinoflagellate bloom analyzed by DGGE and 16S rDNA sequencing. Aquat Microb Ecol 23:119-130

* Fuhrman J, Azam F (1982) Thymidine incorporation as a measure of heterotrophic bacterioplankton production in marine surface waters: evaluation and field results. Mar Biol 66:109-120

Gargas E (1975) A manual for phytoplankton primary production studies in the Baltic. Baltic Marine Biologists Publication No. 2. Water Quality Institute, Hørsholm

* Gasol JM, del Giorgio PA (2000) Using flow cytometry for counting natural planktonic bacteria and understanding the structure of planktonic bacterial communities. Sci Mar 64:197-224

Gómez-Consarnau L, Lindh MV, Gasol JM, Pinhassi J (2012) Structuring of bacterioplankton communities by specific dissolved organic carbon compounds. Environ Microbiol 14:2361-2378

Granéli E, Hansen PJ (2006) Allelopathy in harmful algae: a mechanism to compete for resources? In: Granéli E, Hansen PJ (eds) Ecology of harmful algae, Book 189. Springer, Berlin, p 189-201 
Grasshoff K, Ehrhardt M, Kremling K (eds) (1983) Methods of seawater analysis. Verlag Chemie, Weinheim

Harris G (1986) Phytoplankton ecology: structure, function, and fluctuation. Chapman \& Hall, London

Heiskanen A (1998) Factors governing sedimentation and pelagic nutrient cycles in the northern Baltic Sea. Monographs of the Boreal Environment Research 8. Finnish Environment Institute, Helsinki, p 1-80

HELCOM (Helsinki Commission) (2008) Programme for monitoring of eutrophication and its effects. Annex C-11 Guidelines concerning bacterioplankton growth determination. In: Manual for Marine Monitoring in the COMBINE Programme of HELCOM. HELCOM, Helsinki, Annex C-1:9

Herlemann DP, Labrenz M, Jürgens K, Bertilsson S, Waniek JJ, Andersson AF (2011) Transitions in bacterial communities along the $2000 \mathrm{~km}$ salinity gradient of the Baltic Sea. ISME J 5:1571-1579

Herlemann DP, Lundin D, Andersson AF, Labrenz M, Jürgens K (2016) Phylogenetic signals of salinity and season in bacterial community composition across the salinity gradient of the Baltic Sea. Front Microbiol 7:1883

Höglander H, Larsson U, Hajdu S (2004) Vertical distribution and settling of spring phytoplankton in the offshore NW Baltic Sea proper. Mar Ecol Prog Ser 283:15-27

Hoikkala L (2012) Dynamics of dissolved organic matter and its bioavailability to heterotrophic bacteria in the Gulf of Finland, northern Baltic Sea. PhD thesis, University of Helsinki

Hoikkala L, Kortelainen P, Soinne H, Kuosa H (2015) Dissolved organic matter in the Baltic Sea. J Mar Syst 142: $47-61$

Hoppe HG, Gocke K, Koppe R, Kraus G (2006) Changing bacterioplankton growth characteristics on a large spatial scale: oligotrophic versus mesotrophic ocean. Mar Ecol Prog Ser 323:21-33

Hoppe HG, Breithaupt P, Walther K, Koppe R, Bleck S, Sommer U, Jürgens K (2008) Climate warming in winter affects the coupling between phytoplankton and bacteria during the spring bloom: a mesocosm study. Aquat Microb Ecol 51:105-115

Hugerth LW, Larsson J, Alneberg J, Lindh MV, Legrand C, Pinhassi J, Andersson AF (2015) Metagenome-assembled genomes uncover a global brackish microbiome. Genome Biol 16:279

Jeong HJ, Du Yoo Y, Kim JS, Seong KA, Kang NS, Kim TH (2010) Growth, feeding and ecological roles of the mixotrophic and heterotrophic dinoflagellates in marine planktonic food webs. Ocean Sci J 45:65-91

Jespersen AM, Christoffersen K (1987) Measurements of chlorophyll a from phytoplankton using ethanol as extraction solvent. Arch Hydrobiol 109:445-454

Kirchman DL (2002) The ecology of Cytophaga-Flavobacteria in aquatic environments. FEMS Microbiol Ecol 39: 91-100

Kirchman DL, Cottrel MT, DiTullio GR (2017) Shaping of bacterial community composition and diversity by phytoplankton and salinity in the Delaware Estuary, USA. Aquat Microb Ecol 78:93-106

Klais R, Tamminen T, Kremp A, Spilling K, Olli K (2011) Decadal-scale changes of dinoflagellates and diatoms in the anomalous Baltic Sea spring bloom. PLOS ONE 6: e21567

Klais R, Tamminen T, Kremp A, Spilling K, An BW, Hajdu S, Olli K (2013) Spring phytoplankton communities shaped by interannual weather variability and dispersal limitation: mechanisms of climate change effects on key coastal primary producers. Limnol Oceanogr 58:753-762

*Krausse GL, Schelske CL, Davis CO (1983) Comparison of three wet-alkaline methods of digestion of biogenic silica in water. Freshw Biol 13:73-81

* Kremp A, Anderson DM (2000) Factors regulating germination of resting cysts of the spring bloom dinoflagellate Scrippsiella hangoei from the northern Baltic Sea. J Plankton Res 22:1311-1327

Kremp AEM, Schweikert M, Wolny JL, Gottschling M (2005) Woloszynskia halophila (Biecheler) comb. nov.: a bloomforming cold-water dinoflagellate co-occurring with Scrippsiella hangoei (Dinophyceae) in the Baltic Sea. J Phycol 41:629-642

KKremp A, Tamminen T, Spilling K (2008) Dinoflagellate bloom formation in natural assemblages with diatoms: nutrient competition and growth strategies in Baltic spring phytoplankton. Aquat Microb Ecol 50:181-196

* Laas P, Simm J, Lips I, Lips U, Kisand V, Metsis M (2015) Redox-specialized bacterioplankton metacommunity in a temperate estuary. PLOS ONE 10:e0122304

* Landa M, Cottrell M, Kirchman D, Kaiser K and others (2014) Phylogenetic and structural response of heterotrophic bacteria to dissolved organic matter of different chemical composition in a continuous culture study. Environ Microbiol 16:1668-1681

Kanda M, Blain S, Christaki U, Monchy S, Obernosterer I (2016) Shifts in bacterial community composition associated with increased carbon cycling in a mosaic of phytoplankton blooms. ISME J 10:39

Lekunberri I, Lefort T, Romera-Castillo C, Cardelús C and others (2012) Relationship between induced phytoplankton blooms and the structure and dynamics of the freeliving heterotrophic bacterial community. Mar Ecol Prog Ser 448:23-37

Lignell R, Kaitala S, Kuosa H (1992) Factors controlling phyto- and bacterioplankton in the late spring on a salinity gradient in the northern Baltic. Mar Ecol Prog Ser 84: 121-131

Lignell R, Heiskanen AS, Kuosa H, Gundersen K, KuuppoLeinikki P, Pajuniemi R, Uitto A (1993) Fate of a phytoplankton spring bloom: sedimentation and carbon flow in the planktonic food web in the northern Baltic. Mar Ecol Prog Ser 94:239-252

Lindh MV, Riemann L, Baltar F, Romero-Oliva C, Salomon PS, Granéli E, Pinhassi J (2013) Consequences of increased temperature and acidification on bacterioplankton community composition during a mesocosm spring bloom in the Baltic Sea. Environ Microbiol Rep 5: 252-262

Lindh MV, Sjöstedt J, Andersson AF, Baltar F and others (2015) Disentangling seasonal bacterioplankton population dynamics by high-frequency sampling. Environ Microbiol 17:2459-2476

炎Lips I, Rünk N, Kikas V, Meerits A, Lips U (2014) Highresolution dynamics of the spring bloom in the Gulf of Finland of the Baltic Sea. J Mar Syst 129:135-149

* López-Sandoval DC, Rodríguez-Ramos T, Cermeño P, Marañón E (2013) Exudation of organic carbon by marine phytoplankton: dependence on taxon and cell size. Mar Ecol Prog Ser 477:53-60

Manly BF (2006) Randomization, bootstrap and Monte Carlo methods in biology. Chapman \& Hall/CRC, Boca Raton, FL 
Martin M (2011) Cutadapt removes adapter sequences from high-throughput sequencing reads. EMBnet J 17:10-12

McArdle BH, Anderson MJ (2001) Fitting multivariate models to community data: a comment on distance-based redundancy analysis. Ecology 82:290-297

Menden-Deuer S, Lessard EJ (2000) Carbon to volume relationships for dinoflagellates, diatoms, and other protist plankton. Limnol Oceanogr 45:569-579

Meon B, Kirchman DL (2001) Dynamics and molecular composition of dissolved organic material during experimental phytoplankton blooms. Mar Chem 75:185-199

Morán XAG, Estrada M, Gasol JM, Pedrós-Alió C (2002) Dissolved primary production and the strength of phytoplankton-bacterioplankton coupling in contrasting marine regions. Microb Ecol 44:217-223

Myklestad SM (1995) Release of extracellular products by phytoplankton with special emphasis on polysaccharides. Sci Total Environ 165:155-164

Myklestad SM (2000) Dissolved organic carbon from phytoplankton. In: Wangersky PJ (ed) Marine chemistry. The handbook of environmental chemistry (Vol 5, Series: Water Pollution). Springer, Berlin, p 111-148

*Nielsen ES (1952) The use of radio-active carbon $\left(\mathrm{C}^{14}\right)$ for measuring organic production in the sea. ICES J Mar Sci 18:117-140

Norland S (1993) The relationship between biomass and volume of bacteria. In: Kemp PF, Sherr BF, Sherr EB, Cole JJ (eds) Handbook of methods in aquatic microbial ecology. Lewis, Boca Raton, FL, p 303-307

Olenina I, Hajdu S, Edler L, Andersson A and others (2006) Biovolumes and size-classes of phytoplankton in the Baltic Sea. HELCOM Baltic Sea Environment Proceedings No. 106. Baltic Marine Environment Protection Commission, Helsinki Commission, Helsinki

* Parrish CC, Bodennec G, Gentien P (1994) Time courses of intracellular and extracellular lipid classes in batch cultures of the toxic dinoflagellate, Gymnodinium cf. nagasakiense. Mar Chem 48:71-82

Paulson JN, Stine OC, Bravo HC, Pop M (2013) Differential abundance analysis for microbial marker-gene surveys. Nat Methods 10:1200-1202

* Pinhassi J, Berman T (2003) Differential growth response of colony-forming $\square$ - and $\square$-proteobacteria in dilution culture and nutrient addition experiments from Lake Kinneret (Israel), the eastern Mediterranean Sea, and the Gulf of Eilat. Appl Environ Microbiol 69:199-211

*Pinhassi J, Sala MM, Havskum H, Peters F, Guadayol O, Malits A, Marrasé C (2004) Changes in bacterioplankton composition under different phytoplankton regimens. Appl Environ Microbiol 70:6753-6766

* Putt M, Stoecker DK (1989) An experimentally determined carbon: volume ratio for marine 'oligotrichous' ciliates from estuarine and coastal waters. Limnol Oceanogr 34: 1097-1103

* Quast C, Pruesse E, Yilmaz P, Gerken J and others (2013) The SILVA ribosomal RNA gene database project: improved data processing and web-based tools. Nucleic Acids Res 41:D590-D596

R Development Core Team (2011) R: a language and environment for statistical computing. R Foundation for Statistical Computing, Vienna

Riemann L, Steward GF, Azam F (2000) Dynamics of bacterial community composition and activity during a mesocosm diatom bloom. Appl Environ Microbiol 66: $578-587$
Riemann L, Leitet C, Pommier T, Simu K, Holmfeldt K, Larsson U, Hagström $\AA$ (2008) The native bacterioplankton community in the central Baltic Sea is influenced by freshwater bacterial species. Appl Environ Microbiol 74: 503-515

Sakshaug E, Bricaud A, Dandonneau Y, Falkowski PG and others (1997) Parameters of photosynthesis: definitions, theory and interpretation of results. J Plankton Res 19: 1637-1670

Sarmento H, Gasol JM (2012) Use of phytoplankton-derived dissolved organic carbon by different types of bacterioplankton. Environ Microbiol 14:2348-2360

Sarmento H, Morana C, Gasol JM (2016) Bacterioplankton niche partitioning in the use of phytoplankton-derived dissolved organic carbon: quantity is more important than quality. ISME J 10:2582-2592

Schloss PD, Westcott SL, Ryabin T, Hall JR and others (2009) Introducing mothur: open-source, platform-independent, community-supported software for describing and comparing microbial communities. Appl Environ Microbiol 75:7537-7541

* Sebastián M, Gasol JM (2013) Heterogeneity in the nutrient limitation of different bacterioplankton groups in the Eastern Mediterranean Sea. ISME J 7:1665

Shiah FK, Ducklow HW (1997) Bacterioplankton growth responses to temperature and chlorophyll variations in estuaries measured by thymidine:leucine incorporation ratio. Aquat Microb Ecol 13:151-159

* Simon M, Azam F (1989) Protein content and protein synthesis rates of planktonic marine bacteria. Mar Ecol Prog Ser 51:201-213

Smith DC, Azam F (1992) A simple, economical method for measuring bacterial protein synthesis rates in seawater using ${ }^{3} \mathrm{H}$-leucine. Mar Microb Food Webs 6:107-114

* Smith DC, Steward GF, Long RA, Azam F (1995) Bacterial mediation of carbon fluxes during a diatom bloom in a mesocosm. Deep Sea Res II 42:75-97

Solorzano L, Sharp JH (1980) Determination of total dissolved phosphorus and particulate phosphorus in natural waters. Limnol Oceanogr 25:754-758

Spilling K (2007) On the ecology of cold-water phytoplankton in the Baltic Sea. PhD thesis, University of Helsinki

Spilling K, Lindström M (2008) Phytoplankton life cycle transformations lead to species-specific effects on sediment processes in the Baltic Sea. Cont Shelf Res 28: 2488-2495

Spilling K, Markager S (2008) Ecophysiological growth characteristics and modeling of the onset of the spring bloom in the Baltic Sea. J Mar Syst 73:323-337

* Spilling K, Kremp A, Klais R, Olli K, Tamminen T (2014) Spring bloom community change modifies carbon pathways and $\mathrm{C}: \mathrm{N}: \mathrm{P}: \mathrm{Chl}$ a stoichiometry of coastal material fluxes. Biogeosciences 11:7275-7289

* Stepanauskas R, Moran MA, Bergamaschi BA, Hollibaugh JT (2003) Covariance of bacterioplankton composition and environmental variables in a temperate delta system. Aquat Microb Ecol 31:85-98

*Tamminen T, Andersen T (2007) Seasonal phytoplankton nutrient limitation patterns as revealed by bioassays over Baltic Sea gradients of salinity and eutrophication. Mar Ecol Prog Ser 340:121-138

Teeling H, Fuchs BM, Becher D, Klockow C and others (2012) Substrate-controlled succession of marine bacterioplankton populations induced by a phytoplankton bloom. Science 336:608-611 
Teeling H, Fuchs BM, Bennke CM, Krüger K and others (2016) Recurring patterns in bacterioplankton dynamics during coastal spring algae blooms. eLife 5:e11888

Teira E, Martínez-García S, Calvo-Díaz A, Morán XAG (2010) Effects of inorganic and organic nutrient inputs on bacterioplankton community composition along a latitudinal transect in the Atlantic Ocean. Aquat Microb Ecol 60:299-313

Thornton DC (2014) Dissolved organic matter (DOM) release by phytoplankton in the contemporary and future ocean. Eur J Phycol 49:20-46

Trick CG, Andersen RJ, Harrison PJ (1984) Environmental factors influencing the production of an antibacterial metabolite from a marine dinoflagellate, Prorocentrum minimum. Can J Fish Aquat Sci 41:423-432

Urbani R, Magaletti E, Sist P, Cicero AM (2005) Extracellular carbohydrates released by the marine diatoms Cylindrotheca closterium, Thalassiosira pseudonana and Skeletonema costatum: effect of P-depletion and growth status. Sci Total Environ 353:300-306

Utermöhl H (1958) Zur Vervollkommnung der quantitativen Phytoplankton-Methodik. Mitt Int Ver Theor Angew Limnol 9:1-38

von Scheibner M, Dörge P, Biermann A, Sommer U, Hoppe HG, Jürgens K (2014) Impact of warming on phytobacterioplankton coupling and bacterial community

Editorial responsibility: Klaus Jürgens,

Rostock, Germany composition in experimental mesocosms. Environ Microbiol 16:718-733

* Wasmund N, Nausch G, Matthäus W (1998) Phytoplankton spring blooms in the southern Baltic Sea - spatio-temporal development and long-term trends. J Plankton Res 20:1099-1117

* Wasmund N, Tuimala J, Suikkanen S, Vandepitte L, Kraberg A (2011) Long-term trends in phytoplankton composition in the western and central Baltic Sea. J Mar Syst 87:145-159

* Wasmund N, Nausch G, Feistel R (2013) Silicate consumption: an indicator for long-term trends in spring diatom development in the Baltic Sea. J Plankton Res 35:393-406

Wasmund N, Kownacka J, Göbel J, Jaanus A and others (2017) The diatom/dinoflagellate index as an indicator of ecosystem changes in the Baltic Sea. 1. Principle and handling instruction. Front Mar Sci 4:22

WWetz MS, Wheeler PA (2007) Release of dissolved organic matter by coastal diatoms. Limnol Oceanogr 52:798-807

* Yang C, Li Y, Zhou B, Zhou Y and others (2015) Illumina sequencing-based analysis of free-living bacterial community dynamics during an Akashiwo sanguinea bloom in Xiamen sea, China. Sci Rep 5:8476

Zhang J, Kobert K, Flouri T, Stamatakis A (2014) PEAR: a fast and accurate Illumina Paired-End reAd mergeR. Bioinformatics 30:614-620

Submitted: March 9, 2017; Accepted: January 5, 2018 Proofs received from author(s): March 15, 2018 